This PDF is a selection from a published volume from the National Bureau of Economic Research

Volume Title: Globalization in Historical Perspective

Volume Author/Editor: Michael D. Bordo, Alan M. Taylor and Jeffrey G. Williamson, editors

Volume Publisher: University of Chicago Press

Volume ISBN: 0-226-06598-7

Volume URL: http://www.nber.org/books/bord03-1

Conference Date: May 3-6, 2001

Publication Date: January 2003

Title: Crises in the Global Economy from Tulips to Today Author: Larry D. Neal, Marc D. Weidenmier

URL: http://www.nber.org/chapters/c9596 


\title{
Crises in the Global Economy from Tulips to Today \\ Contagion and Consequences
}

\author{
Larry Neal and Marc Weidenmier
}

\subsection{Introduction}

As the global financial system has evolved since 1971, financial historians have become increasingly struck by similarities between the stresses and setbacks that have occurred in international financial markets and those that plagued earlier attempts at creating a global financial system. The decade of the 1990s was beset by exchange rate crises in Asia and meltdowns of emerging markets in the former centrally planned economies. Likewise, the decade of the 1890s a century earlier saw a series of financial crises that threatened to become systemic at times. Just as the booming U.S. capital markets in the late 1990s seemed to help stabilize the international financial system at the time, so did the flurry of new activity in the London Stock Exchange promote a rise of international liquidity in the late 1890s. Just as leading commentators on the state of financial markets at the end of the twentieth century argued that the provision of liquidity to financial markets by the actions of the U.S. Federal Reserve System only made the dangers of financial fragility more serious when the markets inevitably collapsed, so did serious analysts, especially R. H. Palgrave (1903), criticize the actions of the Bank of England in the 1890s.

The similarity between the financial pressures and varied responses of participating countries to the emergence of global capital markets in the 1890s and 1990s has not gone unnoticed by economic historians. Bordo and Eichengreen (1999) look systematically at the characteristics of crises par-

Larry Neal is professor of economics at the University of Illinois at Urbana-Champaign and a research associate of the National Bureau of Economic Research. Marc Weidenmier is assistant professor of economics at Claremont McKenna College and a faculty research fellow of the National Bureau of Economic Research. 
ticularly in the gold standard period to determine the extent to which inferences may be drawn about the roles of capital mobility, fixed exchange rates, and financial regulation in those earlier crises. Bordo and Schwartz (1999) have made a useful catalog of crises, distinguishing between banking crises that interrupt the internal payments system and currency crises that disrupt the external payments relations. Kindleberger $(2000)^{1}$ has provided a checklist of financial crises going back to the tulip mania of 1636 in Holland and up to the Asian crisis of 1997 and the subsequent Russian and Brazilian crises in 1998.

The interpretations placed on these historical experiences of international financial crises by the respective authors reflect, ultimately, their judgments whether today's global financial market needs an international lender of last resort (Kindleberger) or a time-consistent set of monetary rules among the participating countries (Bordo). If contagion, the spread of a financial crisis from the country of origin to innocent trading partners or geographical neighbors whose financial fundamentals are sound, is a frequent consequence of a financial crisis, then surely a lender of last resort is a good idea. Injection of liquidity at the appropriate time in the center of the crisis could forestall scrambles for liquidity from trading partners or allies. If, on the other hand, crises spread mainly because trading partners have either weak currencies or fragile banking systems, then credible commitments to a sound currency and conservative banking practices need to be acquired by countries participating in a global financial system. Lurking behind each viewpoint is a historical judgment call: Either the consequences of financial crises are so dire they should be averted when at all possible, or they provide useful learning experiences that can lead to ever sounder financial and monetary systems. Relying on a lender of last resort to bail out one's unwise or risky loans, by contrast, removes the incentives for developing either sound financial institutions or monetary arrangements.

The classic account of financial contagions, Kindleberger's Manias, Panics, and Crashes (2000), presents a standard pattern in which speculative fevers are caused by the appearance of new, unusually profitable investment opportunities. Often, the new opportunities accompany movements toward globalization as new markets or technologies appear that can be exploited by a given country or by an economic sector in several countries. Prices of the new assets that are created in response to the new opportunity are driven to unsustainable heights; panic eventually occurs and investors then scramble to withdraw their funds, not only from the original market but also from any other market that resembles it. The renewed possibilities of contagion in the global capital markets of the twenty-first century have

1. Reflecting the renewed interest in financial crises and contagion, this work came out in its fourth edition in November 2000. 
created concerns for national policymakers and for international organizations charged with maintaining order in the international marketplaces (e.g., Baig and Goldfajn 1999; Classens and Forbes 2001).

Countering these concerns with contagion in financial markets, academic economists have distinguished between "contagion" and "interdependence." Propagation of a financial shock from the origin economy to one or more host economies may occur through the channels of short-term credit flows if the economies are interdependent by virtue of substantial trade with each other and substantial investments in each other (Frankel and Rose 1998). Contagion, however, should not be restricted to economies that are relatively insular, as even normally interdependent economies with substantial flows of trade and factor movements with each other may be subject to contagion - if propagation of the financial shock is more rapid and widespread than reactions to normal fluctuations in trade and capital movements. Noting that recent financial crises in the late 1990s created increased turbulence in related markets, they ask whether the increase in correlation among, say, bond prices or stock market indices that accompanied the Asian financial crisis starting in July 1997 was due simply to the statistical effect that an increase in variance of two variables will raise their measured correlation. If, after adjusting for the effect on correlation of increased variance, there is no increase in correlation among the financial markets after a crisis, the case for contagion disappears (Forbes and Rigobon 1999). All that remains, then, is the normal responses to each other's difficulties that will arise among interdependent economies. So also, presumably, the case for a lender of last resort would disappear. The force of this argument depends on whether one thinks that prior interdependence was a good thing, enlarging the country's production possibilities, rather than a bad thing, simply setting it up for a fallout from a crisis in any of its trading partners. If a good thing originally, then common lessons learned should be beneficial as well and not averted. Another possibility is that interconnected countries are struck by a system-wide shock that has similar effects on each country - for example, the oil shocks of the 1970s on the oilimporting countries. Whether a lender of last resort would have coped better with the Organization of Petroleum Exporting Countries (OPEC) cartel than the learning experience that actually occurred depends on one's appraisal of the consequences of the crisis and then of the lessons learned.

Below, we consider Kindleberger's historical examples of international crises and contagion in chronological sequence, asking in each case (a) what is the evidence for contagion, judged by the standards set by analysts of the crises of the 1990s, and (b) what were the consequences of the crisis for the evolution of financial and monetary systems? The crises considered are the tulip mania of 1637, the Mississippi and South Sea bubbles of 1719-20, the Latin American debt crisis of 1825, the international crisis of 1873, the Barings crisis of 1890 , the stock market crises of 1893 , the panic of 1907 , the 
Wall Street crashes of 1929 and 1987, and the Asian crises of 1997. Kindleberger picks on the crises of 1720, 1873, 1890, and 1929 as cases of international financial crises whose consequences were especially severe and there was no lender of last resort (Kindleberger, 2000, 207). ${ }^{2}$ We deal with other, minor episodes in passing, but pay special attention to the crises of 1873 , 1890, 1893, and 1907 using new, high-frequency data from a wide range of financial markets in those years of the classic gold standard. These also happen to be the same international financial crises identified by Goodhart and Delargy (1998) as yielding analogies to today's financial crises. As we shall see, the evidence for contagion is mixed, as is the evidence for learning. Historical circumstances count for a great deal, today as in the past, but we insist that learning has occurred and can continue to occur. Implementation of the institutional reforms required to avert financial crises in the future, however, depends upon the political will and sense of common peril among policymakers.

\subsection{The Tulip Mania of 1636-37}

The first financial crisis of note after the European "discoveries" of the trading and exploitation possibilities in the rest of the world-especially the West Indies, the East Indies, and Africa - was the tulip mania in Holland, 1637 (Garber 2000). Despite the attention paid to this episode by the chroniclers of human folly, Garber's analysis of this dramatic episode reduces it to a month's worth of idle speculation by burgers confined to bars in the city of Haarlem at the height of the Thirty Years' War during an outbreak of the plague. These individuals, short of capital and long on leisure, knowingly made unenforceable bargains on common tulips for delivery in six months. In fact, their bargains were not enforced, save at 3.5 to 10.0 percent of the original amount, for those traders wishing to continue in the tulip business afterward. Such capital as was bound up in these futures contracts, however, was seen by the authorities as a diversion from more useful investments in government bonds to continue financing the Dutch war effort. The government's hostility to such private uses of funds during wartime accounts for the negative press that the tulip mania received at the time, which has been continued by generations of historians ever since.

In Garber's economic analysis, however, the prices usually quoted as examples of speculative excess were, indeed, normal for first-generation bulbs of unusual beauty that could be used to reproduce generations of subsequent blooms, which naturally fell sharply in price as production grew. Later markets for bulbs in normal times, whether for tulips or hyacinths, show similar high prices for the originals and rapid declines afterwards.

2. Kindleberger also points to the domestic crises of 1882 in France and 1921 in Britain where no lender of last resort acted, but these were limited to the country of origin. 
Furthermore, there seems to have been no contagion to other financial centers from the tulip speculation as such, although the financial demands of the Thirty Years' War upon the commercial cities and towns of the European continent created disruptions as well.

While Kindleberger leads off his chapter on "Domestic Contagion" with a critique of Garber's analysis (Kindleberger 2000, 109-10), the evidence he cites from other secondary works emphasizes the general prosperity of the Dutch republic after the mania had passed and prices had collapsed. The inference he draws implicitly is that building canals and luxury residences were also silly speculations by the Dutch. Most historians, and contemporaries, however, attribute the prosperity of the Dutch in this "golden age" to the profits they extracted as an entrepôt for Protestant forces in northern Europe during the Thirty Years' War, 1618-48. Especially beneficial was their monopoly of the Baltic trade as they circumvented the Spanish blockade to the Mediterranean and even established trading colonies in the West Indies (Israel 1995). The closest thing to contagion was speculation in other commodity derivatives in the summer of 1636 in other Dutch towns, but these, like the tulip mania in Haarlem, are attributed to the outbreaks of plague and the quarantines imposed by municipal authorities on traveling merchants (de Vries and van der Woude 1997, 150-51).

The main outcome of the financial crises attending the Thirty Years' War, however, was the promotion of lasting financial innovations, creating perpetual or life annuities that could be easily transferred to third parties. These were issued by individual cities in northern Europe that were forced to pay kontributionen to warlords maintaining armies in their vicinity (Redlich 1959). When the armies moved on, leaving the structures of the town intact if the payment had sufficed, the town's debts remained but were serviced indefinitely from the local tax base. Eventually, these were marketed to citizens in adjacent towns and cities as well, laying the basis for the "financial revolution" in public finance of the later seventeenth century (Tracy 1985). The lessons learned by the Dutch were evident in their emphasis on promoting overseas trade by maintaining a joint stock company for the Asian trade (the Dutch East India Company), unifying the mint standards of the provinces, facilitating merchant payments through a public exchange bank in Amsterdam, and assigning specific excise taxes for the service of government debts issued mainly by the individual cities and provinces (Neal 2000). The golden age of the Dutch Republic ensued, the contagion of the tulip mania safely contained.

\subsection{The Mississippi and South Sea Bubbles of 1719-20}

Nearly a century after the tulip mania in Holland, the French and British governments created the Mississippi and South Sea bubbles, stock market schemes designed to reduce the burden of debt service, given weak govern- 
ments that lacked the authority to raise taxes. Both governments sought to swap the bulk of their outstanding debt for equity in large joint-stock trading companies with monopoly privileges - the Mississippi Company (Compagnie des Indes) in France and the South Sea Company in Great Britain. Both efforts had the full support of the government currently in power, and both were successful ultimately in reducing the respective debt burdens, at the expense of debt holders who delayed converting their debt holdings or who failed to sell out their equity holdings before the crash. The two schemes were connected through international capital movements, as investors from both the Netherlands and Great Britain were first attracted to John Law's investment opportunities in France from July to December 1719 , and then to the rising stock markets in London from March to September 1720. By October 1720, however, both schemes had collapsed, thanks mainly to the total disruption of the European payments system in the summer of 1720 . This was caused mostly by Law's efforts to rescue his system from the dangers of capital flight (by letting the French currency depreciate rapidly, he hoped to induce speculative inflows in anticipation of the revaluation that would follow), but complicated by the last outbreak of the plague on the European continent and the quarantines imposed by municipal authorities.

Much has been made of the supposed contagion of irrational speculation that swept across northern Europe in these two years (Kindleberger 2000, 77-78, 122-29; Chancellor 1999, chap. 3), but recent work by economists has reduced both to essentially rational, if premature, schemes to relieve pressure on government finances (Neal 1990; Murphy 1997; Carswell 1993). The lesson of history is not that contagion occurred, but that the two countries suffered a common shock - the excessive debt created by the enormous expenses of the War of the Spanish Succession.

The aftermath of the bubbles, however, laid the basis for the rise of an international capital market, increasingly centered in the city of London. Most important for the future success of the capital markets in Great Britain, the huge mass of illiquid "Irredeemable Ninety-nine Year Annuities" that had constituted the major part of British national debt in 1719 had been largely converted by 1723 into liquid, easily tradable, and transparently priced South Sea annuities. This greatly enlarged mass of tradable financial assets in the secondary market for securities in London preserved an active stock market in London, more than offsetting the effects of the Bubble Act of 1720.

The Bubble Act eliminated dealing in a welter of bubble companies that had sprung up in the previous speculative boom, but does not seem to have eliminated continued use of the joint-stock company for financing the continued expansion of British infrastructure-turnpikes, canals, docks, and waterworks (Harris 2000). The basic outlines of the Anglo-American structure of finance were set by 1723 - a complementary set of private 
commercial and merchant banks all enjoying continuous access to an active, liquid secondary market for financial assets, especially government debt. The South Sea Bubble proved to be the "big bang" for financial capitalism in England. In 1726, even the Bank of England had to acknowledge the success of the South Sea Company's 3 percent perpetual annuity when it issued its own "Three Per Cent Annuity."

Unfortunately for France, the collapse of the Mississippi Bubble there in 1720 proved to be the end of secondary markets for financial assets in that country (Hoffman, Postel-Vinay, and Rosenthal 2000). In the inflation that had accompanied Law's efforts to create a market for the Mississippi Company shares, French debtors had repaid their bonds in depreciated currency, inflicting large and long-lasting losses on French creditors. Only a limited market for private debt arose after the currency reform of 1726, and that was a primary market mediated by the public notaries in Paris (Hoffman and Rosenthal 1995). Amsterdam's capital market survived the collapse of the minibubbles that had popped up there at the end of 1720, but continued to be fragmented among the various bonds issued by the Generalitet of the United Provinces and the individual cities and provinces. Only the shares of the new marine insurance company created in response to the financial innovations in Paris and London remained as a new investment opportunity for Dutch savers. For the most part, they focused first on the increasing issues of national debt created by the British government (Dickson 1967) and then on bonds issued by various European governments after mid-century (Riley 1980). The British, French, and Dutch governments learned different lessons from the first international financial crisis.

\subsection{After the Bubbles}

Financial crises in the remainder of the eighteenth century were caused by shocks from the aftermath of war finance, but usually had quite different effects among the financial centers of London, Amsterdam, and Paris. During the Seven Years' War (1756-63), which caused bankruptcies among the public notaries in Paris and put an end to the efforts of the most enterprising to become de facto bankers, the most spectacular military victories won by the British were in India. The territorial gains there and rewards by grateful Indian princes yielded the promise of greatly increased profits for the East India Company. Speculation could be financed in Amsterdam by drawing bills of exchange on the basis of credits expected from the Bank of England as it remitted bills payable in Amsterdam to support its mercenary troops on the Continent, as well as the troops of Frederick the Great. This led to wisselruiterij, a Dutch version of check-kiting (writing checks on a demand deposit before the check has cleared for the original deposit), that came to a sudden and widely embarrassing halt in 1763. A chain of bankruptcies then occurred in Amsterdam and Hamburg, where the British sub- 
sidies had been directed. According to Wilson (1941, 168-69), however, the crisis was short-lived and focused on the least reputable bankers. London bankers, who had not been involved in wisselsruiterij, perhaps due to a lack of opportunity or in sophistication in the use of the Wisselbank's facilities, sent large shipments of specie to their most reliable correspondents. The London bankers and the Bank of England also temporarily suspended requests for payment of their bills in Amsterdam. The connections between the sources of public credit for the British government and the instruments of private credit for foreign trade between London and Amsterdam were thereby sustained and even strengthened.

A similar liquidity crisis, however, occurred again in 1772, also the result of speculation on East India Company stock. But the only response in the Amsterdam financial sector this time was to patch together a Loan Bank to serve as a form of deposit insurance by helping to recapitalize merchant banks that were temporarily illiquid. Even the connections with the London capital market were weakened as Dutch rentiers withdrew their holdings of British national debt in favor of seeking placements in other European government debt (Riley 1980).

The learning experience of these first stock market bubbles and crashes varied, then, depending whether we take Great Britain, France, or the Netherlands as our object of study. While Kindleberger asserts that the consequences were prolonged and destructive to all three economies, economic historians remark that the following quarter-century was one of remarkable prosperity for all three countries, chiefly due to the absence of major war until the War of the Austrian Succession (Tracy 1990). The French financial system was weakened permanently, however, while the British benefited from the creation of a liquid secondary market for successive issues of its national debt and the Dutch connection with London benefited both (Neal 2000). The case for a lender of last resort is strongest in the French experience, weakest in the British, unless one thinks of the reorganization of the South Sea Company in 1723 as a delayed action of a reluctant lender of last resort - the Bank of England acting under political duress from the administration of Robert Walpole.

\subsection{The First Latin American Debt Crisis in 1825}

After the disruptions to financial markets caused by the French Revolution and the wars that ensued until 1815, the London stock exchange emerged as the dominant capital market in the world. The first foray of British investors into international finance, however, ended in disaster with the crash of 1825 . The origins of the 1825 crisis began with the withdrawal of foreigners from the British national debt after the war. Following the final defeat of Napoleon at Waterloo in 1815, capital flowed back to the European continent from Great Britain. Foreign holdings of British debt di- 
minished rapidly, the price of consols rose as the supply diminished, and prices of Bank of England and East India stock rose in tandem. British investors, used to safe returns ranging between 4 and 6 percent for the past twenty years now, found their options limited to yields between 3.5 and 4.5 percent. The opportunities for investment in new issues of French 5 percent rentes were more attractive than continuing their holdings in consols. Indeed, the rentes maintained a steady return over 5 percent throughout the crisis period and offered a stable alternative to the British funds.

Baring Brothers and Co., by its successful finance of Wellington's army in 1815, had established itself as the dominant merchant bank in England. By undertaking the flotation of the first two issues of French rentes sold to pay the reparations and support Wellington's occupation forces, Barings became the "Sixth Power" in Europe, according to the Duc de Richelieu (Jenks 1927, 36). ${ }^{3}$ From February to July 1817, Barings disposed of three loans, the first two at a net price of 53 for 100 million francs each and the third at 65 which raised 115 million francs. Yet, according to the historian of the Baring firm, no disturbance in the British trade balance or in French reserves seems to have occurred - the inflow of capital to France from Great Britain from the issue of rentes seems to have been offset by indemnity payments and army contracts from France to Great Britain (Jenks, 37). (What the historian has missed, of course, is the fall in the exchange rate of the British pound that occurred at the time; the pound was still floating after the suspension of convertibility in February 1797.) From this success for British investors in foreign investment with the French rentes, it has traditionally been argued, came increased enthusiasm for other forms of investment, first in the bonds issued by the new government of Spain established in 1820, and then in the bonds issued by the new states emerging in Latin America. ${ }^{4}$

The collapse of Spanish control over its American empire during the Napoleonic Wars led to the formation of a variety of independent states from the former colonies by 1820. Battling one another for control over strategic transport routes, mainly rivers and ports, and over state enterprises, mainly mines, each appealed to foreign investors as a source of government finance and as a means to substitute foreign expertise and technology for the vanquished Spanish. Their government bonds and their mining shares found a ready market in the London Stock Exchange, which had become the dominant marketplace for finance capital in the world during the Napoleonic Wars. The loan bubble of 1822-25 ensued, eventually

3. See also Ziegler 1990, 100-11.

4. While the focus for foreign loans was mostly on Spain and Spanish America, literature buffs may be forgiven for thinking instead of Greece, which received a loan and much-needed publicity for its then-premature efforts to break away from Turkish rule. Over fifty years later, when the Greek government was attempting to assure the international community it would go on a gold standard, part of its commitment was to resume payment on these initial bonds! 


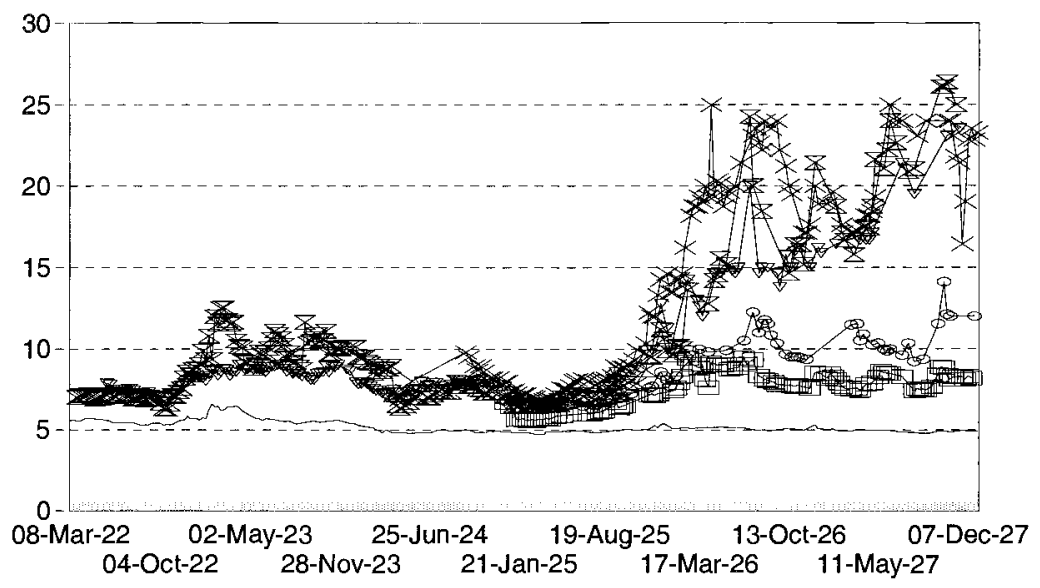

- French $\quad$ Brazil $\rightarrow$ Araentine $-z$-Columbia $-\nabla$ - Chile $\nleftarrow$ Peru

Fig. 10.1 Yields of Latin bonds, 1822-27

giving British foreign bondholders their first experience with defaults by sovereign states. None of the new Latin American states emerging from the remains of the Spanish empire (Brazil remained part of the Portuguese empire) found the means, whether by exports or taxes, to service the debts they had incurred in London. Meanwhile, they dissipated rapidly in military conflicts with neighboring states the net proceeds they received after the bonds were sold at discount and they had paid large commissions up front to the London investment houses. ${ }^{5}$

From 1822, when both Chile and Colombia floated bond issues with London agents, an increasing number of Latin American governments tried to find the means for financing their transition to independence from the flush pockets of British investors. The bonds they issued, in terms of the amounts actually paid up, as distinguished from the amounts actually received by the governments, were the largest single category of new investment in the London capital market in this period (Gayer, Schwartz, and Rostow 1975, 189). It is true, even so, that the amount was small relative to the remaining sum of the British government's funded debt—£43 million compared to $£ 820$ million. ${ }^{6}$

Figure 10.1 compares the prices of several bond issues of the emerging

5. Dawson (1990) provides a readable account of this episode, but Marichal (1989) puts it into a longer run Latin American perspective. Brazilians point with pride that their bonds never went into default, which is why their prices remained the highest among the Latin American bonds in the late 1820s. The Brazilian bonds, in fact, were the only ones issued by the Rothschilds. None of their government bond issues for Austria, Belgium, Naples, Prussia, or Russia defaulted in this period. (Doubleday, 1847, 281).

6. Gayer, Rostow, and Schwartz (vol. 1, p. 408n. 8) and Mitchell (1962, 402). These are nominal values in each case, but government debt was then trading at close to par, so its market value was roughly the same. 
Stock Market Crisis of 1825

\begin{tabular}{|c|c|c|c|c|c|}
\hline & \multicolumn{2}{|c|}{ Correlation Coefficient } & & & \\
\hline & Precrisis & Postcrisis & & & \\
\hline Index & 0.794 & 0.521 & & & \\
\hline French rentes & 0.848 & -0.197 & & & \\
\hline Colombia 6\% & 0.881 & 0.328 & & & \\
\hline Chile $6 \%$ & 0.910 & 0.190 & & & \\
\hline \multicolumn{6}{|l|}{ U.K. var } \\
\hline \multirow{4}{*}{$\begin{array}{l}\text { Precrisis } \\
\text { Postcrisis }\end{array}$} & \multirow{2}{*}{\multicolumn{5}{|c|}{$\begin{array}{r}12.740 \\
4.031\end{array}$}} \\
\hline & & & & & \\
\hline & \multicolumn{2}{|c|}{$\begin{array}{l}\text { Adjusted Correlation } \\
\text { Coefficient }\end{array}$} & \multicolumn{3}{|c|}{ Contagion } \\
\hline & Precrisis & Postcrisis & SE Precrisis & SE Postcrisis & Test \\
\hline Index & 0.914 & 0.724 & 0.166 & 0.282 & $-0.423 N C$ \\
\hline French rentes & 0.940 & -0.327 & 0.139 & 0.386 & $-2.411 N C$ \\
\hline Colombia 6\% & 0.955 & 0.513 & 0.122 & 0.350 & $-0.936 N C$ \\
\hline Chile $6 \%$ & 0.967 & 0.316 & 0.105 & 0.387 & $-1.323 N C$ \\
\hline
\end{tabular}

South American states, as given in James Wetenhall's semiweekly Course of the Exchange. At the peak of the stock market boom, there was surprising convergence in the prices of all the Latin American bonds. It was only in the ensuing two years that information on the fiscal capacity of the individual governments and their respective economic bases enabled the London market to distinguish among them. Mexico and the Andean countries were clearly marked to be disaster cases by the end of 1828, while already Argentina and Brazil were demonstrating their attractiveness to British investors, an allure that would increase until the Barings crisis of 1890 .

To see if this early financial crisis is properly another example of contagion, we have analyzed the cross-correlations of various asset prices in the London Stock Exchange during the first Latin American debt crisis in the 1820s, which led to the financial crisis of December 1825. Using the prices of the Three Percent Consol as the reference security, table 10.1 shows that correlations were quite high before the crisis between the price of consols, a general index of stock market prices, the price of French rentes (a seasoned foreign security), and the first Latin American bonds issued by Colombia and Chile. After the crisis, correlations broke down and, contrary to the recent stock market crises, the variance of the reference asset in this case actually declined. Consequently, adjusting for heteroscedasticity actually increases the likelihood of finding evidence of contagion, but even so, the hypothesis of contagion from the collapse of Latin American bond prices to the stock market index, or mature bond markets, is resoundingly rejected.

The lesson learned by the British government in this case was to make 
major changes in the financial structure of Great Britain, reforming the bankruptcy law, repealing the Bubble Act of 1720, and forcing the Bank of England to open branches in the major commercial and industrial cities, while maintaining the gold standard and avoiding most Latin American involvements for another quarter-century. If the Bank of England acted as a lender of last resort, it was erratic, belated, and ultimately inadequate. ${ }^{7}$ In the view of modern economic historians, however, this set the stage for the true industrial revolution in the British economy - the beginning of sustained increases in per capita income, increases sustained to the present day. It may be, then, that other reforms in the financial architecture of a country can compensate for the absence of an effective lender of last resort.

\subsection{The Gold Standard Emerges}

Meanwhile, European countries took note of the superiority of the British public financial system that Great Britain had conclusively demonstrated during the Napoleonic Wars from 1803 to 1815. The lesson was clear, but adapting the British system to Continental conditions was a slow and painful process, marked by numerous setbacks as European governments clung as long as possible to their traditional fiscal regimes, monetary standards, and financial institutions. Over the course of the nineteenth century, the individual European nation-states gradually moved as best they could toward an imitation of the obviously successful British system of public finance. Issuing perpetual annuities backed by the permanent taxing authority of an elected parliament was a key element in the British system, but the reigning monarchs of Europe only reluctantly ceded authority over taxation to their parliaments.

Constraining the growth of the money supply with a credible rule such as the gold standard was also important, not least to maintain the market value of the debt issued by a government. But no country was willing to follow the British example of a gold standard, set in 1821, until little Portugal adopted gold as its monetary standard in 1854. Then it took the FrancoPrussian War in 1870 to get united Germany to adopt a gold standard to replace the varieties of silver standards among the various German states. France, and its major trading partners in Europe, persisted with the bimetallic standard, maintaining a mint ratio of 15.5:1.0 of silver to gold until 1871. Then, the flood of German silver on the market as the German Empire replaced the silver coinage with either gold or token coins led France and the other members of the Latin Monetary Union to demonetize silver, effectively adopting the gold standard as well after 1879 (Flandreau 1996).

With the adoption by 1880 of a nearly universal regime of fixed exchange

7. Comments by Michael Bordo on Neal (1998). 
rates within Europe, a truly Europe- (and Atlantic-) wide financial market arose quickly, which came to encompass much of Latin America (Argentina and Brazil) and Asia (India) as well as Australia (Gallarotti 1995). It served well to finance an impressive surge of international trade as well as labor and capital movements that remain benchmarks for today's global marketplace. The trade, labor, and capital movements of the period were clearly driven by technological revolutions in steam-driven transport, electrical communication, and agricultural mechanization (O'Rourke and Williamson 2000). All of these epochal changes placed immense new demands upon the international financial markets as well, which in turn expanded rapidly their depth and range of services.

While previous analysts have focused on either the bond market (Ferguson 2001; Bordo and Murshid 2000) as an indicator of long-term capital movements, or on exchange rates as an indicator of credible commitment to the gold standard (Bordo and MacDonald 1997), we have chosen to focus on the open market interest rates for three-month accommodation bills, which were reported weekly in The Economist newspaper. While the discount rates at the public banks of issue on the European continent remained sticky compared to the Bank of England, the open market rates were much more responsive to market conditions. Table 10.2 demonstrates dramatically how much more volatile were short-term interest rates on three-month trade bills than the long-term interest rates on the respective government bonds. For the five countries shown, the standard deviations of the short-term rates we use for our analysis of the transmission of financial crises were several times greater than the standard deviations of the longterm rates. In the cases of Great Britain and Germany, the difference was nearly 10 times. In the statistical analysis below, we concentrate on correlations of movements in interest rates in this short-term capital market. It was the short-term capital market that had the greatest volume of trading activity, financing not only the continually rising volume of domestic and foreign trade arising from the transportation revolution of the steam age, but also the temporary liquidity needs of financial intermediaries. This so-called "money market" was precisely where we expect pressures from liquidity de-

Table 10.2

Interest Rate Volatility During the Classical Gold Standard Period, 1880-1914

\begin{tabular}{lcc}
\hline & \multicolumn{2}{c}{ Standard Deviation } \\
\cline { 2 - 3 } Country & Long-term Bonds & Short-term Market Bills \\
\hline Austria & 0.375 & 0.712 \\
France & 0.299 & 0.682 \\
Germany & 0.169 & 1.11 \\
The Netherlands & 0.317 & 0.917 \\
United Kingdom & 0.217 & 1.17 \\
\hline
\end{tabular}


"Contagious" Crises during the Classical Gold Standard Period

\begin{tabular}{|c|c|c|}
\hline & Precrisis & Postcrisis \\
\hline Panic of 1873 & 21 September $1872-13$ September 1873 & 20 September $1873-12$ September 1874 \\
\hline $\begin{array}{l}\text { Barings crisis } \\
\text { of } 1890\end{array}$ & 5 October 1889-27 September 1890 & 4 October 1890-26 September 1891 \\
\hline $\begin{array}{l}\text { U.S. Banking } \\
\text { Crisis of } 1893\end{array}$ & 8 October $1892-7$ October 1893 & 13 October 1893-29 September 1894 \\
\hline Panic of 1907 & 22 October $1906-19$ October 1907 & 26 October $1907-17$ October 1908 \\
\hline
\end{tabular}

mands by banks to be expressed, raising discount rates when demands for cash surged and lowering discount rates when the supply of cash was plentiful. Indeed, even Kindleberger notes that it was the short-term capital market that was the usual, and most effective, transmission mechanism for the examples of contagion he cites, which become exceptionally numerous in this period (Kindleberger 2000, chap. 8).

The analysis below draws upon the extensive data set we have compiled specifically for this study. The data set comprises weekly observations on prices of long-term government bonds and interest rates on three-month, prime-quality trade bills determined in national capital markets and the discount rates charged by their public banks for fourteen countries over the period 1 January 1870 through 27 June 1914 (see the appendix for a full description.) Including over 100,000 observations, this rich data set, now available to researchers, can be used for detailed analyses of the transmission process of financial disturbances in the world's first global financial market. We use it in this study to focus on the issue of whether contagion characterized the financial crises of the gold standard period. Table 10.3 show the dates of the crises and the periods we analyze pre- and postcrisis.

\subsection{The Crisis of 1873}

We begin with the 1873 crisis, which is considered to have started in Germany and Austria but was amplified by the repercussions in the United States, still in the greenback period. Table 10.4 shows the correlation coefficients between the market interest rates on call money in New York and, respectively, Paris, Berlin, Amsterdam, Brussels, Vienna, and Petersburg, and three-month bills in London. ${ }^{8}$ Germany had just adopted the gold standard formally, but was still in the process of replacing the silver coinage. Paris, Amsterdam, Brussels, and Vienna were bimetallic but suffering the aftershock of Germany's switch from silver to gold and the flood of silver coming into their mints.

8. All interest rate data for the period 1873-1914 were deseasonalized using the ESMOOTH facility in RATS, which is based on the Holt-Winters exponential smoothing algorithm. 


\begin{tabular}{|c|c|c|c|c|c|}
\hline & \multicolumn{2}{|c|}{ Correlation Coefficient } & & & \\
\hline & Precrisis & Postcrisis & & & \\
\hline France & 0.664 & 0.429 & & & \\
\hline Germany & 0.144 & 0.281 & & & \\
\hline The Netherlands & -0.099 & 0.284 & & & \\
\hline Belgium & -0.016 & 0.476 & & & \\
\hline Austria & 0.187 & 0.680 & & & \\
\hline Russia & 0.259 & -0.235 & & & \\
\hline United Kingdom & 0.098 & 0.163 & & & \\
\hline \multicolumn{6}{|l|}{ U.S. var } \\
\hline Precrisis & -0.209 & & & & \\
\hline \multirow[t]{3}{*}{ Postcrisis } & -0.824 & & & & \\
\hline & \multicolumn{2}{|c|}{$\begin{array}{c}\text { Adjusted Correlation } \\
\text { Coefficient }\end{array}$} & \multicolumn{3}{|c|}{ Contagion } \\
\hline & Precrisis & Postcrisis & SE Precrisis & SE Postcrisis & Test \\
\hline France & 0.409 & 0.232 & 0.135 & 0.143 & $-0.635 \mathrm{NC}$ \\
\hline Germany & 0.073 & 0.146 & 0.147 & 0.146 & $0.248 \mathrm{NC}$ \\
\hline The Netherlands & -0.050 & 0.147 & 0.147 & 0.146 & $0.674 \mathrm{NC}$ \\
\hline Belgium & -0.008 & 0.263 & 0.147 & 0.142 & $0.935 \mathrm{NC}$ \\
\hline Austria & 0.095 & 0.423 & 0.147 & 0.134 & $1.168 \mathrm{NC}$ \\
\hline Russia & 0.134 & -0.121 & 0.146 & 0.146 & $-0.870 \mathrm{NC}$ \\
\hline United Kingdom & 0.409 & 0.232 & 0.135 & 0.143 & $-0.635 \mathrm{NC}$ \\
\hline
\end{tabular}

The last column in table 10.4 indicates whether there is evidence of contagion $(\mathrm{C})$ or not $(\mathrm{NC})$ between the London market rate and the market rate of the country in question. None of the seven cases show contagion on the Forbes and Rigobon criterion, after adjusting for heteroscedasticity, although Austria does increase its correlation considerably while failing the one-sided $t$-statistic test of +1.65 . While we have taken the United States as the source of the crisis, Kindleberger might well argue that Austria was the source. It certainly was the weakest financial sector, with the AustroHungarian monarchy struggling with the aftermath of its defeat at the hands of Prussia in 1866 and the triumph of the German reich establishing a gold standard in 1871. Rather than a case of possible contagion, Austria's apparent response to the U.S. crisis can also be interpreted as a defensive reaction in common with the United States to maintain their gold stocks in response to German pressures.

These statistical measures of contagion are completely at odds with the standard story of the 1873 crisis. According to Kindleberger, the crisis was initiated by the speculative excesses in Germany resulting from the reparations payments extracted from France after its defeat in 1870; the German mania spilled over into Austria in 1871 and 1872. Both stock market bub- 
bles collapsed in May 1873, with contagion spreading to Italy, Holland, and Belgium, eventually taking in the United States in September 1873 (Kindleberger 2000,131-32). If that was a process of contagion, then we should have found the correlation of Austria and the United States falling after the collapse of Jay Cook's firm in September 1873, not rising as it did. The panic in the United States, which we take as the crisis point, was followed by a worldwide depression in trade and economic activity that lasted until 1879 and that encompassed France and Russia, neither of which shared in the initial euphoria and so were exempted from the crash.

The cases of Austria and the United States show that, even in the absence of a lender of last resort or any close substitute for the actions of such a lender, effective steps were taken to limit their correlations with the epicenter of the crisis, Germany in this case. Other unpleasant economic consequences followed from their respective resolves to hasten deflation and return to a fixed metallic standard (the United States in 1879 when the economy picked up again, and Austria not until the early 1900s when it was finally successful in shadowing the gold standard). Financial contagion, however, was not, on our reading of the statistical evidence in the shortterm capital markets of the time, part of the picture, but the gold standard system was incomplete, still in its formative years.

\subsection{The Crisis of 1890}

The Barings crisis of 1890 forced Portugal and Argentina off the gold standard, while leaving Great Britain breathing a collective sigh of relief in the financial sector. Governor Lidderdale of the Bank of England coordinated a swap of equity for debt among the major banking houses of London so they could take over much of the Barings business while forestalling a run on them by their clients. But as he admitted freely, his efforts would likely have failed had it not been for the pledges of support by the Banque de France and the British government. ${ }^{9}$ What seems surprising at first glance is that the gold centers experienced much more volatile market and bank rates through these three crisis years than did the smaller, more vulnerable trading centers such as Vienna, Madrid, and Genoa. Figure 10.2, panels $\mathrm{A}$ and $\mathrm{B}$, highlights the contrast in performance by the respective money markets of the core and periphery countries in Europe. The much lower volatility of both the bank and market rates in the periphery countries compared to the bank and money rates in the core countries persisted right through the crisis year of 1890 , the effects of which are impossible to discern in panel B.

The explanation of lower volatility in the periphery than the core cannot

9. Kindleberger (2000, 151-52, 184-85), drawing on the authoritative account of Pressnell (1968). 


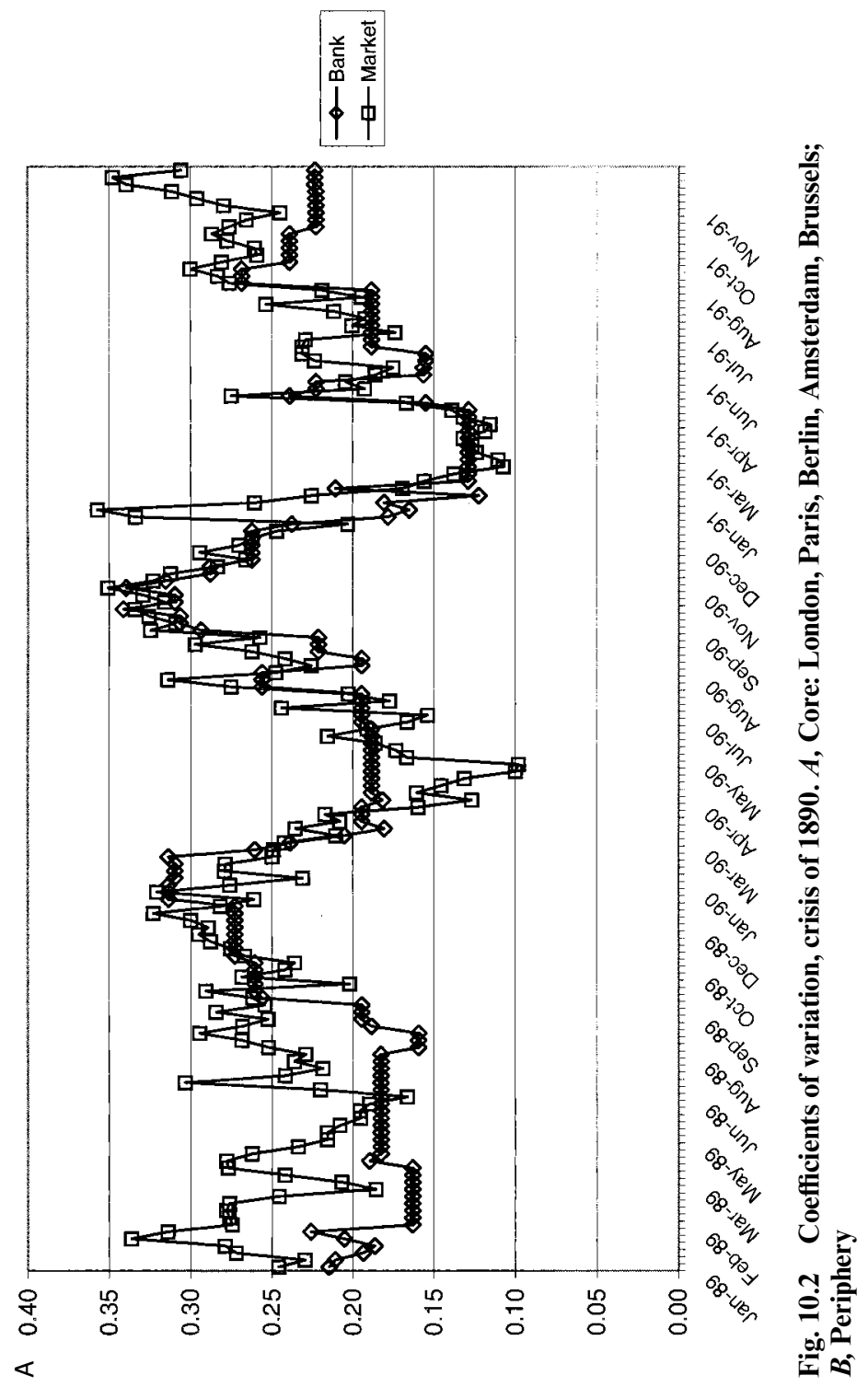




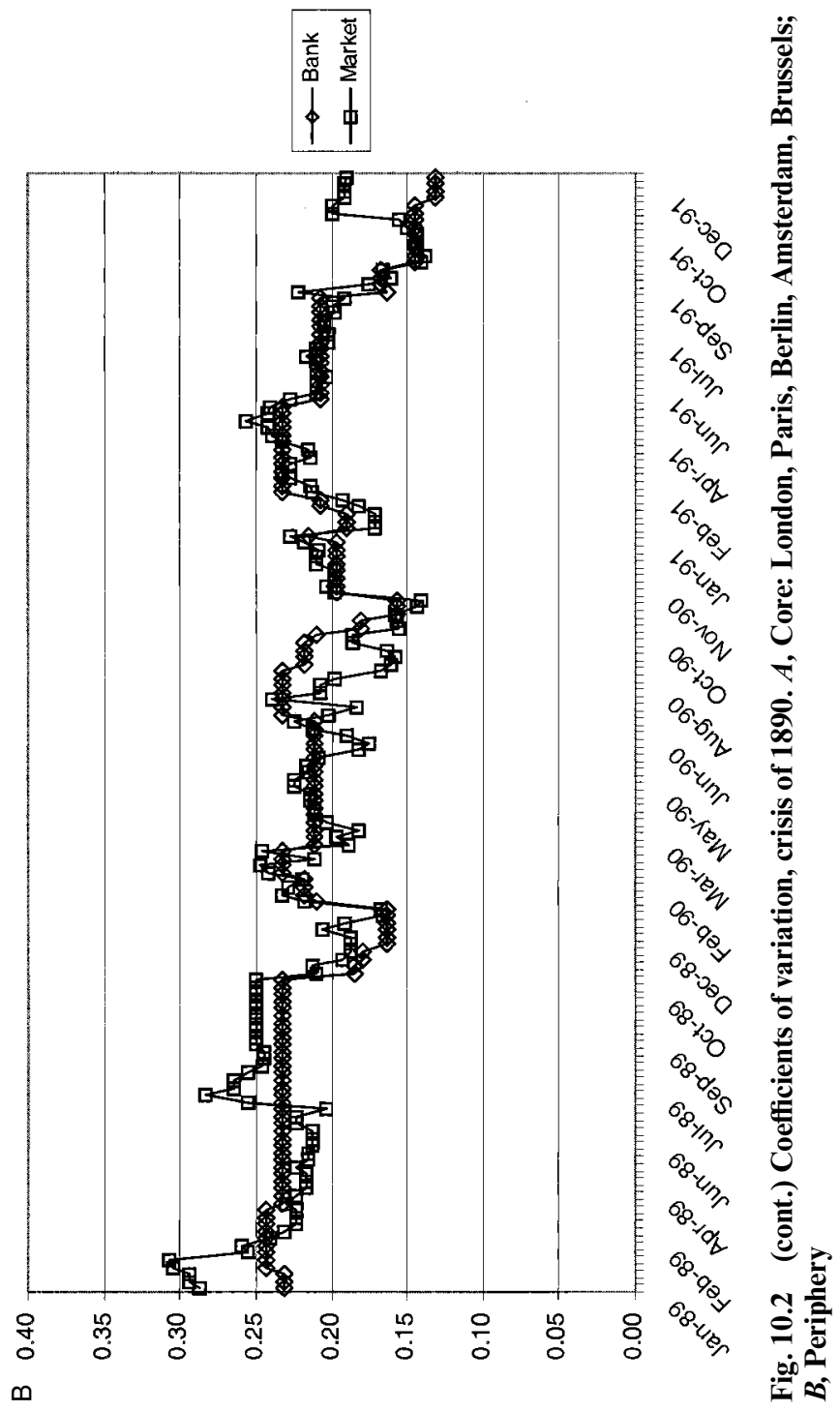


be that only the credit markets of the large industrial countries were affected by the crisis; trade intensity among the European continental countries was still rising in the 1880s despite signs of reversal in the free trade movement that had begun in the 1860 s. It seems self-evident that the less advanced countries were using their public banks to limit access to trade credit through informal credit rationing. Their implicit capital controls were clearly effective, as their respective money markets mirrored faithfully both the stable levels and the low volatility of the very stable bank rates. Bloomfield $(1959,28)$ identified the variety of informal capital controls that central banks employed when under duress in the gold standard period, although he hesitated to draw any definite conclusions about the policy implications of his anecdotal evidence. Schumpeter, on the other hand, asserted that every commercial bank was assigned a ration and "such ration was cyclically varied as well as currently revised" $(1939,651)$. The question is whether the behavior of the periphery countries changed over time with experience or with changes in circumstance?

We have even more data on short-term interest rates with which to examine the possibility of contagion from the financial crisis of 1890 , which may have started with a banking crisis in the United States in October, leading to exacerbation of Barings' difficulties with Argentina in November of that year. Table 10.5 gives the results for twelve trading partners, most of whom were on the gold standard at this point, the main exception being Portugal, which left the gold standard in 1890 . The only two cases of possible contagion are Russia and the United States, but again this may be interpreted as a defensive reaction as in the earlier crisis of 1873. Russia did not formally commit to a gold standard until the reforms of Sergei Witte in 1896. The correlations of short-term interest rates in these gold standard markets with the London market were higher, typically, than in 1873 both before and after the crisis of 1890, reflecting the increase in short-term capital flows that accompanied the spread of the gold standard.

Our results can be compared with those reported by Bordo and Murshid (2000), who analyzed the correlation patterns on government bond prices for eight countries before and after the first crisis in April 1890 when the Banco de la Nacion stopped dividend payments, provoking a run on all $\mathrm{Ar}-$ gentine banks, and then before and after the November failure of Baring Brothers. Only in the case of Argentine and British bonds did they find an increase in correlations and then only after the April crisis within Argentina, suggesting the unlikely case that contagion spread from Argentina to Great Britain, or that Argentine bonds became absorbed by the reorganized and recapitalized Barings firm. Both their results and ours indicate that the actions of the governor of the Bank of England in reorganizing Barings while supporting its depositors limited the fallout from this crisis to the English banking establishment in the short run. It may have had 
Table 10.5

Crisis of 1890, Short-Term Capital Markets

\begin{tabular}{|c|c|c|c|c|c|}
\hline & \multicolumn{2}{|c|}{ Correlation Coefficient } & & & \\
\hline & Precrisis & Postcrisis & & & \\
\hline France & 0.211 & 0.546 & & & \\
\hline Germany & 0.442 & 0.698 & & & \\
\hline The Netherlands & -0.164 & 0.280 & & & \\
\hline Belgium & 0.646 & 0.769 & & & \\
\hline Italy & 0.366 & 0.688 & & & \\
\hline Austria & 0.578 & 0.608 & & & \\
\hline Portugal & 0.647 & 0.462 & & & \\
\hline Russia & 0.052 & 0.711 & & & \\
\hline United States & 0.336 & 0.837 & & & \\
\hline Denmark & 0.047 & 0.275 & & & \\
\hline Australia & -0.162 & -0.489 & & & \\
\hline India & -0.302 & 0.095 & & & \\
\hline \multicolumn{6}{|l|}{ U.K. var } \\
\hline \multirow{4}{*}{ Postcrisis } & 0.547 & & & & \\
\hline & 1.513 & & & & \\
\hline & \multicolumn{2}{|c|}{$\begin{array}{c}\text { Adjusted Correlation } \\
\text { Coefficient }\end{array}$} & \multicolumn{3}{|c|}{ Contagion } \\
\hline & Precrisis & Postcrisis & SE Precrisis & SE Postcrisis & Test \\
\hline France & 0.129 & 0.365 & 0.146 & 0.137 & $0.833 \mathrm{NC}$ \\
\hline Germany & 0.284 & 0.506 & 0.141 & 0.127 & $0.825 \mathrm{NC}$ \\
\hline The Netherlands & -0.099 & 0.173 & 0.147 & 0.145 & $0.932 \mathrm{NC}$ \\
\hline Belgium & 0.454 & 0.586 & 0.131 & 0.119 & $0.528 \mathrm{NC}$ \\
\hline Italy & 0.230 & 0.495 & 0.143 & 0.128 & $0.976 \mathrm{NC}$ \\
\hline Austria & 0.392 & 0.418 & 0.136 & 0.134 & $0.098 \mathrm{NC}$ \\
\hline Portugal & 0.454 & 0.299 & 0.131 & 0.141 & $-0.572 \mathrm{NC}$ \\
\hline Russia & 0.031 & 0.519 & 0.147 & 0.126 & $1.786 \mathrm{C}$ \\
\hline United States & 0.210 & 0.677 & 0.144 & 0.109 & $1.849 \mathrm{C}$ \\
\hline Denmark & 0.028 & 0.169 & 0.147 & 0.145 & $0.482 \mathrm{NC}$ \\
\hline Australia & -0.098 & -0.319 & 0.147 & 0.140 & $-0.722 \mathrm{NC}$ \\
\hline India & -0.187 & 0.057 & 0.145 & 0.147 & $0.837 \mathrm{NC}$ \\
\hline
\end{tabular}

more widespread influences, however, in the medium and long run, due to the interconnections of the various money markets that had arisen.

\subsection{The Crisis of 1893}

To see the longer term effects of the 1890 experience we are fortunate that another, more serious, more widespread financial crisis struck in 1893. Panels A and B of figure 10.3 show how the short-term credit markets in Europe responded to this crisis. The volatility of bank rates among the core gold standard countries was nearly as stable during this crisis as in the periphery 


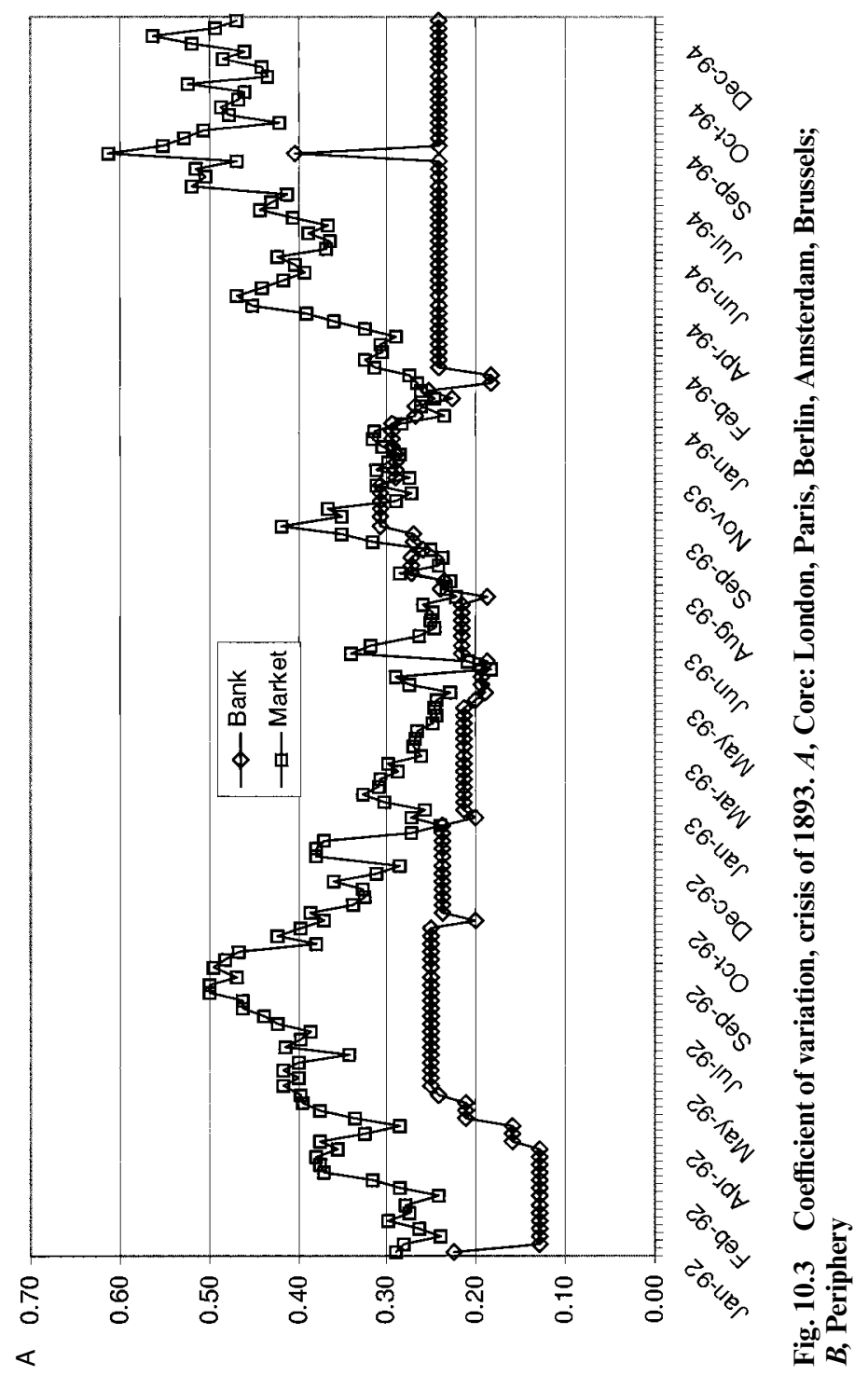




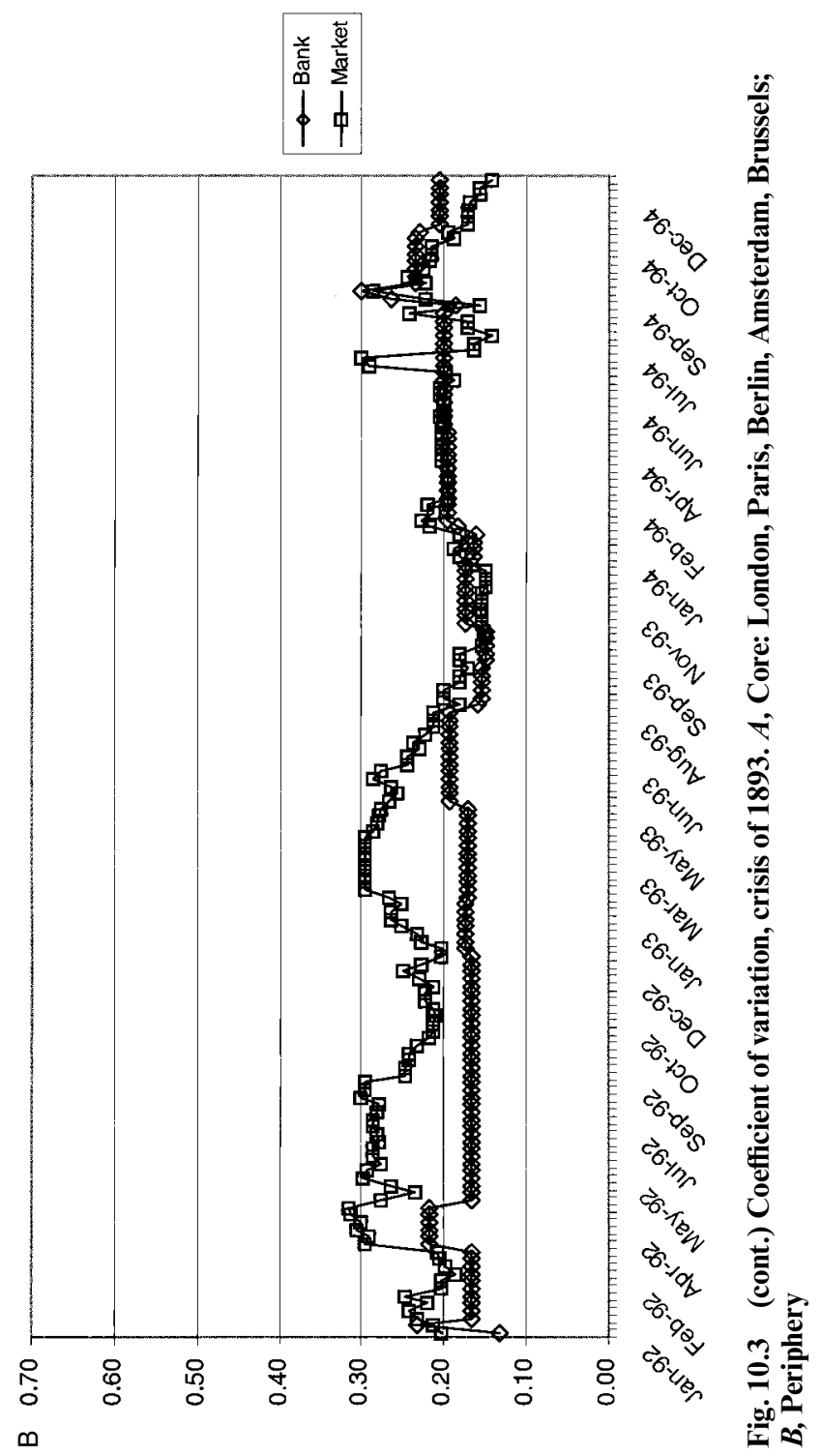


countries, most of whom were merely shadowing the gold standard at this time. Portugal had abandoned it, Russia and Austria had not yet adopted it, Italy was about to drop it, and Spain would never adopt it formally. The real contrast in this crisis came in the open market rates, which, as in the previous crisis of 1890 , were much more volatile in the core countries than in the periphery. We take this again as evidence that credit rationing was effectively administered in the periphery countries, implying de facto capital controls in the periphery, but exposure to external market pressures in the core.

Additional evidence in support of our interpretation of the contrasting results for core and periphery countries in Europe comes from the Australian case in 1893. For Australian economic development, the crisis of 1893 has been interpreted as a major turning point. The large number of branch banks that had financed Australia's "long boom" over the preceding quarter-century had to suspend payments for varying periods during the year 1893 and to consolidate services when they resumed. Despite the internal turmoil that was occurring in the domestic payments system, the discount rates in Melbourne, Sydney, and Adelaide remained rock solid throughout that year and the following years. Indeed, the only sign of trouble that we can pick up in our financial data from The Economist is that it stopped reporting the Australian data altogether in 1894. It was in London's bill market, where most of the Australian banks had their headquarters, that the action occurred.

The crisis of 1893, originating in the United States with a banking crisis combined with a currency crisis created by the Silver Purchase Act of 1893, included Australia, Italy, and Germany in its extent, according to Bordo and Eichengreen (1999). In the short-term capital markets, however, it appears to have created contagion in only three of the twelve cases analyzed in table 10.6. Only the Netherlands, Belgium, and Switzerland, apparently, were affected. All three small countries had essentially no correlation at all with the very volatile call money rates of the United States before the crisis, unlike Italy, France, and Austria. But after the crisis, their correlation with U.S. call money rates shot up significantly. The odd thing about this crisis, however, is that the variance of the central capital market actually fell during the crisis period compared to the precrisis period - from 0.442 to 0.255 . If we were to take the London three-month bill rate as the epicenter of the crisis instead, we would still have the same problem - a decline in variance so that the adjustment of the correlation coefficient for increased variance should actually be reversed, reducing the precrisis correlation. The same conclusion, nevertheless, would emerge - somehow the crisis of 1893 increased the interdependence of the short-term capital markets in the Atlantic trading world for three of the smaller, but very open, economies in Europe while decreasing it for the major economies of France, Italy, and Great Britain. 
Table 10.6

Crisis of 1893, Short-Term Capital Markets

\begin{tabular}{|c|c|c|c|c|c|}
\hline & \multicolumn{2}{|c|}{ Correlation Coefficient } & & & \\
\hline & Precrisis & Postcrisis & & & \\
\hline France & 0.475 & -0.339 & & & \\
\hline Germany & 0.234 & 0.234 & & & \\
\hline The Netherlands & -0.144 & 0.895 & & & \\
\hline Belgium & 0.098 & 0.706 & & & \\
\hline Italy & 0.549 & -0.656 & & & \\
\hline Austria & 0.438 & -0.792 & & & \\
\hline Portugal & 0.228 & 0.150 & & & \\
\hline Russia & -0.077 & -0.717 & & & \\
\hline Switzerland & 0.045 & 0.573 & & & \\
\hline Australia & -0.084 & 0.097 & & & \\
\hline India & -0.187 & -0.715 & & & \\
\hline United Kingdom & -0.170 & -0.523 & & & \\
\hline \multicolumn{6}{|l|}{ U.S. var } \\
\hline Precrisis & 0.442 & & & & \\
\hline \multirow[t]{4}{*}{ Postcrisis } & 0.255 & & & & \\
\hline & \multirow{2}{*}{\multicolumn{2}{|c|}{$\begin{array}{c}\text { Adjusted Correlation } \\
\text { Coefficient }\end{array}$}} & \multirow{2}{*}{\multicolumn{3}{|c|}{ Contagion }} \\
\hline & & & & & \\
\hline & Precrisis & Postcrisis & SE Precrisis & SE Postcrisis & Test \\
\hline France & 0.579 & -0.429 & 0.120 & 0.133 & $-3.977 \mathrm{NC}$ \\
\hline Germany & 0.302 & 0.303 & 0.141 & 0.141 & $0.002 \mathrm{NC}$ \\
\hline The Netherlands & -0.188 & 0.935 & 0.145 & 0.052 & $5.702 \mathrm{C}$ \\
\hline Belgium & 0.129 & 0.795 & 0.146 & 0.089 & $2.831 \mathrm{C}$ \\
\hline Italy & 0.654 & -0.753 & 0.112 & 0.097 & $-6.747 \mathrm{NC}$ \\
\hline Austria & 0.540 & -0.863 & 0.124 & 0.075 & $-7.063 \mathrm{NC}$ \\
\hline Portugal & 0.295 & 0.196 & 0.141 & 0.145 & $-0.346 \mathrm{NC}$ \\
\hline Russia & -0.101 & -0.804 & 0.147 & 0.088 & $-3.002 \mathrm{NC}$ \\
\hline Switzerland & 0.059 & 0.677 & 0.166 & 0.123 & $2.138 \mathrm{C}$ \\
\hline Australia & -0.110 & 0.127 & 0.147 & 0.146 & $0.811 \mathrm{NC}$ \\
\hline India & -0.243 & -0.803 & 0.143 & 0.088 & $-2.424 \mathrm{NC}$ \\
\hline United Kingdom & -0.221 & -0.638 & 0.144 & 0.115 & $-1.574 \mathrm{NC}$ \\
\hline
\end{tabular}

We believe this may again be a defensive reaction limited to the smaller countries with smaller gold reserves at their disposal, compared to the major countries. This may be a further demonstration that the pressures upon the gold standard's viability as an international monetary system were becoming extreme by that time as the American and German economies expanded rapidly and increased their holdings of monetary gold. While the discovery of new sources of gold in South Africa and Alaska in the following years eased the pressures overall from 1897 to the outbreak of World War I, the financial techniques developed by continental bankers in imitation of the British example were also important. We return to this point in 
our conclusion after examining the case, or not, for contagion in the following international financial crises, starting with the one major international financial crisis during the period of gold inflation, 1897-1914.

\subsection{The Crisis of 1907}

After 1897, gold inflation relieved the pressures imposed upon monetary authorities committed either formally or informally to fixed exchange rates under the gold standard system. Not only did currency crises remain on the sideline, but the frequency of banking crises diminished as well. The crisis of 1907, however, was very serious and its effects widespread, extending from the United States to Germany and Italy. Panels A and B of figure 10.4 contrast the results for the core and now a much expanded membership in the periphery. Even with the greater numbers of centers reporting to The Economist by this time, however, the same stability of bank rates and corresponding market rates in the periphery countries remains in sharp contrast to the volatility of market rates in the core countries. Moreover, bank rates were more responsive in the 1907 crisis as more central banks began either to imitate the practices of the Bank of England, or to take defensive measures in response to the bank's frequent changes of discount rate.

In the midst of the gold inflation period, from 1897 to 1914, occurred the most severe and widespread financial crisis before World War I. No doubt that its origin was the United States, but the financial interdependence already developed within the gold standard area meant that its effects were quickly transmitted abroad. While the crisis that caught everyone's attention was the banking crisis with the failure of the Knickerbocker Trust Company of New York in October 1907, the ultimate cause of the crisis was likely the San Francisco earthquake in April 1906. ${ }^{10}$ Naturally, the physical destruction caused by the earthquake put immediate demands upon the financial resources of first the Californian and then the U.S. economy. It was not until October 1906, however, that these pressures were transmitted to London, but then the pressures were sudden and overwhelming as over $£ 50$ million of gold were shipped in that month from London to the United States. The cause was the reluctant decisions by British insurance companies to pay out on the claims lodged by their San Francisco insurees. While the insurance companies had initially claimed that the losses of property in San Francisco were caused by the earthquake, and not by the fires that followed immediately, so they were not liable for payments, they realized that U.S. courts would certainly rule against them. They began payments in October, dealing with six months of accumulated claims.

The effect was twofold: First, the Bank of England raised the discount rate sharply; and second, when it lowered the discount rate in January 1907,

10. This paragraph draws on Odell and Weidenmier (2001). 


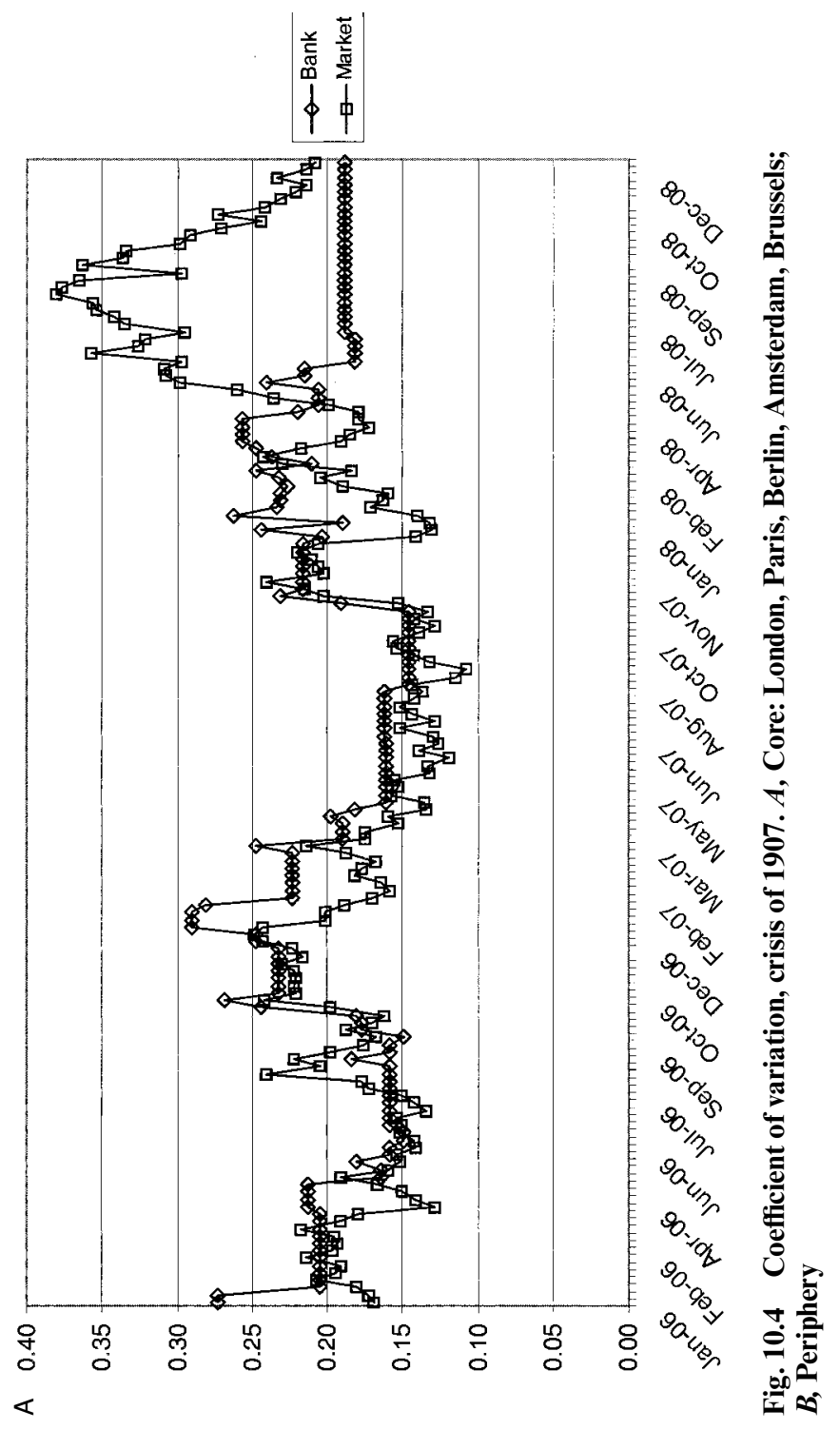




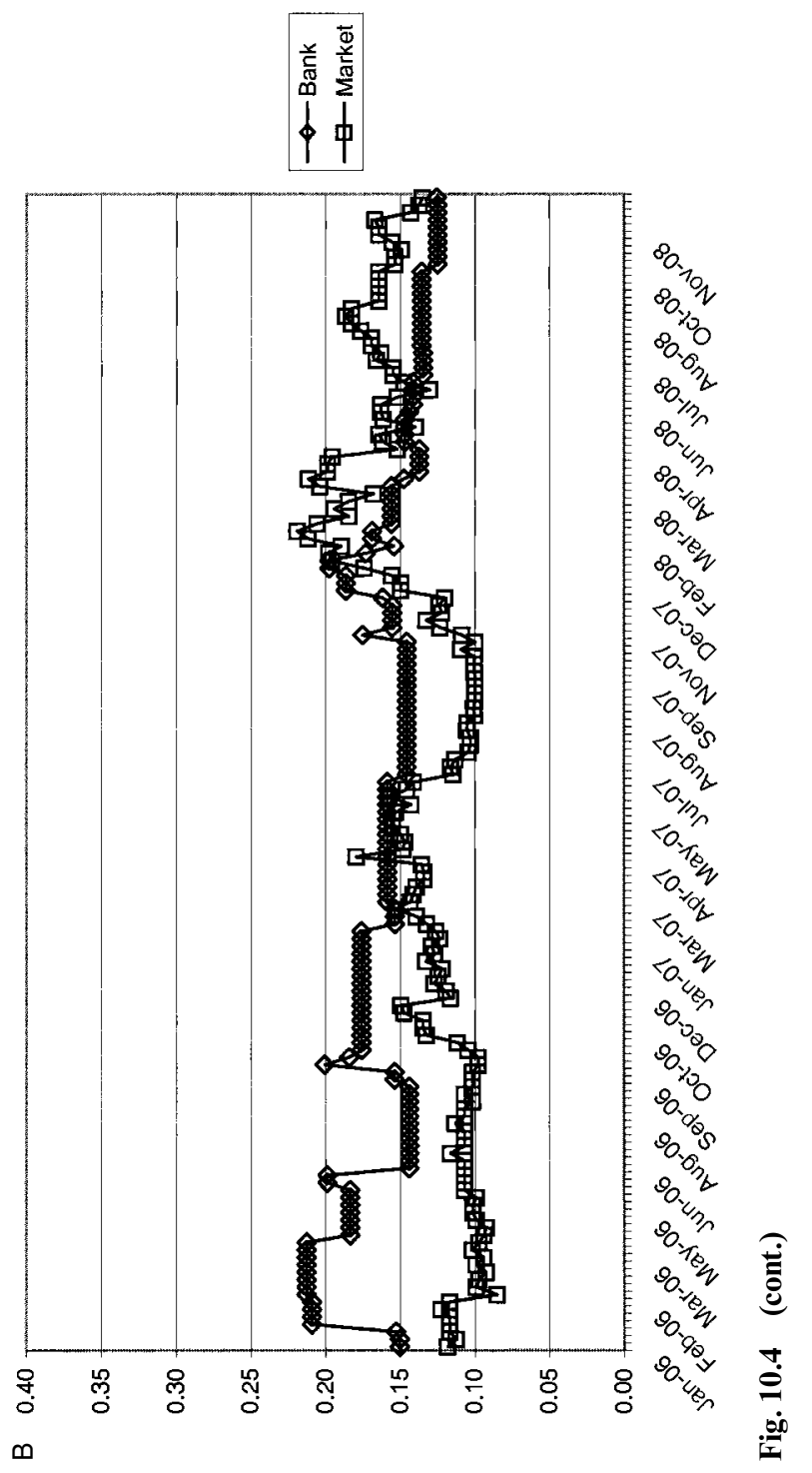


it refused to discount any bills originating from the United States. Ultimately, this cut off New York trust companies from their usual source of funds for financing liquidity demands in the fall. The fall of 1907 saw another large outflow of gold from London to the United States, and this time the response was felt throughout the capital market, transmitting quickly to Germany, France, and Italy.

Table 10.7 shows how dramatic this final episode of the gold standard was for the global financial system of the time. The increase in variance of shortterm interest rates in the London market was the greatest experienced in the entire gold standard period. The evidence of contagion is nearly universal

Table 10.7

Crisis of 1907, Short-Term Capital Markets, Seasonal Adjusted Data

\begin{tabular}{|c|c|c|c|c|c|}
\hline & \multicolumn{2}{|c|}{ Correlation Coefficient } & & & \\
\hline & Precrisis & Postcrisis & & & \\
\hline France & -0.708 & 0.915 & & & \\
\hline Germany & 0.750 & 0.956 & & & \\
\hline The Netherlands & 0.065 & 0.955 & & & \\
\hline Belgium & -0.229 & 0.963 & & & \\
\hline Italy & 0.511 & 0.941 & & & \\
\hline Austria & -0.144 & 0.921 & & & \\
\hline Switzerland & 0.615 & 0.961 & & & \\
\hline United States & 0.788 & 0.952 & & & \\
\hline India & 0.393 & 0.173 & & & \\
\hline Sweden & 0.602 & 0.791 & & & \\
\hline Denmark & 0.746 & 0.744 & & & \\
\hline Spain & 0.460 & 0.595 & & & \\
\hline \multicolumn{6}{|l|}{ U.K. var } \\
\hline Precrisis & 0.723 & & & & \\
\hline \multirow[t]{3}{*}{ Postcrisis } & 3.158 & & & & \\
\hline & \multicolumn{2}{|c|}{$\begin{array}{c}\text { Adjusted Correlation } \\
\text { Coefficient }\end{array}$} & \multicolumn{3}{|c|}{ Contagion } \\
\hline & Precrisis & Postcrisis & SE Precrisis & SE Postcrisis & Test \\
\hline France & -0.432 & 0.735 & 0.133 & 0.100 & $5.014 \mathrm{C}$ \\
\hline Germany & 0.477 & 0.842 & 0.130 & 0.080 & $1.744 \mathrm{C}$ \\
\hline The Netherlands & 0.031 & 0.839 & 0.147 & 0.080 & $3.547 \mathrm{C}$ \\
\hline Belgium & -0.112 & 0.863 & 0.147 & 0.074 & $4.412 \mathrm{C}$ \\
\hline Italy & 0.274 & 0.799 & 0.142 & 0.089 & $2.282 \mathrm{C}$ \\
\hline Austria & -0.069 & 0.749 & 0.147 & 0.098 & $3.345 \mathrm{C}$ \\
\hline Switzerland & 0.350 & 0.857 & 0.138 & 0.076 & $2.369 \mathrm{C}$ \\
\hline United States & 0.522 & 0.830 & 0.125 & 0.082 & $1.480 \mathrm{NC}$ \\
\hline India & 0.200 & 0.084 & 0.144 & 0.147 & $-0.400 \mathrm{NC}$ \\
\hline Sweden & 0.339 & 0.526 & 0.139 & 0.125 & $0.707 \mathrm{NC}$ \\
\hline Denmark & 0.472 & 0.470 & 0.130 & 0.130 & $-0.009 \mathrm{NC}$ \\
\hline Spain & 0.241 & 0.334 & 0.143 & 0.139 & $0.331 \mathrm{NC}$ \\
\hline
\end{tabular}


in Europe - only the Scandinavian gold bloc remained impervious, along with the United States, India, and Spain. Forbes and Rigobon (1999) might classify these results for 1907 as less an example of contagion, however, than of an aggregate shock affecting all the financial centers of the gold standard. The problem with that explanation, of course, is the anomalous case of the United States, the very epicenter of the crisis. But this may be another case where our statistical test is too rigorous, as the $t$-statistic of 1.48 is even closer to the critical value of 1.65 than the case of Austria in 1873. If the U.S. financial market was subjected to special discrimination in this crisis, excluded from the London discount market precisely in the year before the crisis of October 1907, the U.S. anomaly is explained. Effectively, the U.K. interest rate against the U.S. bills of exchange was infinity.

We have, then, a historical example of what can happen when a country is excluded from an interdependent financial system precisely when its financial needs are greatest, as is always the case when a major, unexpected, and unpredictable "bolt from the blue" hits an economy. When interdependence is already high, attempts to shelter the rest of the international system from an idiosyncratic shock in one financial center are likely to prove fruitless. With the benefit of hindsight, we can see that the European centers might have been better off if they had come to the aid of San Francisco, or their own insurance companies, promptly. Of course, if all the governments concerned were nursing their reserves of gold in case a major war were to break out, their actual reaction is understandable.

\subsection{The Greatest Financial Crisis of All: 1929-33}

The issues touched on in our discussion of historical crises are motivated, of course, by our awareness of the tragic consequences of the Great Depression of 1929-33, which all analysts agree was initiated by a truly international financial crisis and most acknowledge that the consequenceseconomic, political, and social - were long-lasting and dire. Here is where Kindleberger's argument for a lender of last resort has its greatest force. Thanks to cooperation between Montagu Norman, governor of the Bank of England, and Benjamin Strong, governor of the Federal Reserve Bank of New York, a working version of the pre-World War I gold standard had been built up over the years 1924-28. While it worked, this "gold exchange standard" provided the financial basis for an expansion of international trade and rapid economic recovery in the major industrial economies. But when a liquidity crisis struck - basically because world agricultural prices fell, making it impossible for farmers from the plains of Nebraska to the pampas of Argentina to the steppes of Hungary to make payments on the debts they had incurred - there was no lender of last resort around. The Bank of England was willing, but incapable with its limited resources, to serve in this role. The Federal Reserve System of the United States was ca- 
pable, but unwilling to play that role, given its dysfunctional internal decision-making procedures. ${ }^{11}$

Our view of this terminal crisis of the gold standard era is that the entire period from the outbreak of World War I in late July 1914 until the collapse of the Bretton Woods system of fixed exchange rates in mid-August 1971 was the antithesis of globalization. The work of Jeffrey Williamson (1995) on convergence of real wages, which made substantial progress in the gold standard years and came to halt in the 1914-45 period, confirms this view. The study of capital movements and the various measures of capital market integration by Maurice Obstfeld and Alan Taylor (1998) identifies this period as one of "de-globalization" as well. Only the brief interlude of 1924-28, which W. A. Lewis (1949) called "the five good years" in his history of the interwar period, had any resemblance to the global economy and its methods of operation that had arisen in the half-century before World War I - and that was based on a flawed financial structure that could not have endured. ${ }^{12}$

From this perspective, which we share with Kindleberger, the key financial crisis was not the Wall Street panic in October 1929, but the failure of the Kreditanstalt Bank in Austria, announced on 11 May 1931. The contagion effects in this crisis were the worst possible for globalization as they consisted of payment defaults that led to a widening circle of exchange controls and a downward spiral of international trade. But in terms of our indicators of contagion, there would be little or no effect, much as we found for the crisis of 1873, at the beginning of the gold standard era.

Indeed, Bordo and Murshid (2000) find a similar outcome in their analysis of correlations of bond prices for twenty-one countries before and after each of three crises they identify in the 1929-33 period. These are the Wall Street crash in October 1929, Britain's departure from the gold standard in September 1931, and the U.S. law passed in May 1933 that allowed devaluation of the U.S. dollar. In general, they find little evidence of contagion, especially after adjusting for the increase in volatility of the British bond prices after September 1931. The only cases that seem to show contagion are Greece and Finland after the U.S. devaluation in 1933, but these may reflect more the importance of U.S. holdings of Greek and Finnish bonds than Kindleberger-style scramble for liquidity.

\subsection{Lessons Learned from Deglobalization}

Nevertheless, the lessons learned are still being discussed today. The idea that the periphery countries always suffer relative to the core countries, a

11. We hope this capsule summary captures the essence of Kindleberger's (1986) argument, expressed in his World in Depression, 1929-1939, as well as in Manias, Panics, and Crashes (2000) and many other places.

12. Eichengreen (1992) is the classic analysis of the plight of the gold exchange standard. 
hint of which comes from the Bordo-Murshid (2000) findings, was articulated most effectively by Mihail Manoilescu, a Romanian economist appalled by the damage Romania suffered as it tried to follow French advice by staying on the gold standard as long as possible while rejecting offers of markets for its oil from Nazi Germany. Manoilescu's ideas found a receptive audience in Argentina, where Raul Prebisch, a young economist in the central bank of Argentina, was similarly appalled at the damage to Argentina's export economy caused by following British advice. Prebisch's ideas persisted long afterward, thanks to his influence in the Economic Commission of Latin America (Love 1996).

After the failure of the World Economic Conference in 1933, the world divided up into mutually exclusive trading blocs: the sterling area, with its imperial preference; the reichsmark bloc, based on bilateral exchange agreements; the Japanese-led "Asian co-prosperity sphere"; and the autarkic economies of the Soviet Union and fascist Spain, Italy, and Portugal. These assorted regional trading blocs and the attempts by Nazi Germany and imperial Japan to expand their regions to become entirely self-sufficient were important elements in the economic background conditions that set the stage for the tragedies of World War II. Whether all this could have been avoided by a lender of last resort acting at the critical crisis (Wall Street crash? Kreditanstalt collapse? Britain leaving gold? U.S. devaluation?) seems doubtful.

What was needed, in Kindleberger's view, was an economic and political hegemon, a role willingly adopted by the United States after World War II as it took the lead in establishing the Bretton Woods system, based on the institutions of the International Monetary Fund (IMF) and the World Bank, with increasing efforts to make the patchwork General Agreement on Tariffs and Trade become effective, eventually turning into the World Trade Organization. The results of the Bretton Woods era, essentially 1958-71 when it was fully functioning as planned, were remarkably good, as shown by Bordo (1993). In particular, financial crises were limited to the occasional currency crisis when a country, usually Great Britain, could no longer sustain its dollar peg, but thanks to capital controls these were confined to the country of origin, so there was never an issue of contagion. But the monetary basis of the Bretton Woods systemthe dollar exchange standard with the dollar fixed in price relative to gold - was also fatally flawed, essentially because the costs of maintaining political hegemony for the United States undermined its ability to act as economic hegemon. After its sudden collapse in 1971, the disintermediation created by the worldwide inflation that followed led to the rise once again of international capital markets, this time in a world of fiat currencies and floating exchange rates, leading to a new series of international financial crises that began to emerge in the late 1980s as capital controls were increasingly lifted. 


\subsection{The New Financial Crises: 1987, 1994, 1997}

The Asian crises started in July 1997 with the collapse of the Thai currency, the baht, as the Bank of Thailand ran out of dollar reserves needed to maintain its peg with the dollar. They quickly spread to other East Asian countries including Malaysia, Indonesia, the Philippines, and, with a lag, South Korea, making a strong case for financial contagion in the global capital market. IMF Staff Papers and the World Economic Outlook have repeatedly referred to the Asian crisis as a prime example of "contagion." IMF loans made to Argentina and Turkey in 2001 were given credit for preventing contagion's spread from the financial difficulties in those countries. Further, recovery has been slow, complicated by political difficulties in each country, although the sharp devaluations of each currency have moderated the fall in gross domestic product.

The most powerful statistical evidence in support of the contagion hypothesis is Baig and Goldfajn (1999). They use the criterion that if correlations among countries' financial markets increase significantly after a crisis, contagion has occurred. Analyzing the correlations among the five afflicted countries for foreign exchange rates, equity market indexes, interest rates, and prices of government bonds, both before and after the crisis, they find strong evidence of contagion in the currency and government bond markets. They find mixed evidence of contagion in the equity markets, until they control for country-specific events and other fundamentals, whereupon contagion appears to have occurred. Certainly, the financial press drew similar conclusions and it may be that managers of emerging market mutual funds decided to cut back their exposures to all Asian markets, anticipating contagion in a self-fulfilling action.

Another argument, however, could be that all five countries were victims of a common shock, namely the sharp rise in the value of the U.S. dollar relative to the Japanese yen, a rise that began in 1996. All five countries had pegged their currencies to the dollar and in the early 1990s, when the dollar was falling relative to the yen, all five had profited by expanding their exports into markets previously dominated by the Japanese. Several also gained from Japanese investment in their economies as Japanese firms relocated production facilities into Thailand and Malaysia. These advantages turned to disadvantages when the dollar began to rise sharply against the yen and the European currencies. This would not have caused a crisis by itself - Singapore, Taiwan, and Hong Kong also had pegged their currencies to the U.S. dollar - but the five crisis countries also had incredibly weak banking systems caused by financing long-term property investments with short-term loans denominated in dollars.

A more substantive objection to the contagion scenario is due to the work of Forbes and Rigobon (1999), who examine the cases of the U.S. stock market crash in October 1987, the Mexican peso crisis in 1994, and 
the East Asian crises in 1997. Unlike Baig and Goldfajn (1999), however, Forbes and Rigobon adjust their postcrisis correlations for the increase in volatility that also occurred and that upwardly biases standard measures of correlation. Making the appropriate adjustment for heteroscedasticity in their correlation measures, they conclude that for stock market indices, at least, interdependence was already high before the crises in question and remained high afterward, showing that contagion did not appear to have been a factor even in these cases. If it had existed, the degree of correlation among the stock markets would have increased after the crisis, independent of the increase in variance. Moreover, they find that when correlations among stock market indices are adjusted for heteroscedasticity in the previous crises of 1987 and 1994, contagion does not appear to have been a factor then, either.

For example, calculating correlation coefficients between indexes of stock market values in twenty-seven countries during the East Asian crisis of 1997, they find evidence of contagion in fifteen of the cases. Adjusting for the increase in variance that occurred in the various markets after July 1997, however, they eliminate the evidence of contagion in all but one case: Italy. And that case is more likely due to Italy's reentry into the European Monetary System in November 1996, reducing exchange risk with the rest of European stock markets, than to any psychological fears overtaking Italian investors.

Performing the same adjustment on correlation coefficients among stock market indices before and after two other major financial crises- the October 1987 collapse of the New York Stock Exchange and the collapse of the Mexican peso in late 1994-Forbes and Rigobon systematically eliminate statistical evidence of contagion. Their conclusion is that "contagion is not simply a high cross-market correlation after a shock. It is a significant increase in this correlation after the shock. The high levels of co-movement across many stock markets during these three tumultuous periods reflects a continuation of strong cross-market linkages, and not a significant shift in these linkages" $(1999,35)$. As they find high levels of correlation before each crisis as well as after, they direct our attention to the causes of interdependence across international equity markets even in periods of relative stability. These cross-market linkages, they suggest, make today's financial markets especially vulnerable to shocks. Kindleberger should approve of this conclusion, although he might shy away from substituting "interdependence" for "contagion" in future writings.

Bordo and Murshid (2000) also examine the behavior of long-term government bonds for the Mexican peso crisis in 1994 and the Asian banking and currency crisis of 1997. Like Forbes and Rigobon (1999), they find little evidence of increased correlation in government bond markets after each crisis. The only case of increased correlation with the Thai government bonds after July 1997 turns out to be Brazilian bonds and U.S. bonds 
(Bordo and Murshid, table 5B). Nevertheless, they do find some evidence that correlations with emerging market government bonds do increase relative to correlations with developed-country government bonds after both the Mexican and Asian crises (tables 6A and 6B). As the current debate over the IMF's role as a potential lender of last resort continues, we are obviously still extracting lessons from current experiences. What insight, then, might be taken from our findings from the gold standard period when changes in contagion occurred as the monetary environment changed from mild deflation to mild inflation?

\subsection{Conclusion: Crisis Connections or Contagions?}

Our formal analysis, above, of the correlations among the market shortterm interest rates before and after the three major crises of the gold standard period leads us to doubt that contagion was an important feature then, even under a regime of fixed exchange rates and open capital markets. Rather, we conclude that different rules of the game were appropriate for different players. Countries that had weak specie reserves and governments prone to budget deficits were well advised not to follow the example of the Bank of England during crisis episodes. Rather than lend freely at a penalty rate when the international markets were roiled by a credit crunch somewhere else in the world, they were better off maintaining their previous discount rates so they could lend judiciously with side conditions to only the most solvent of their customers. This surely inhibited risk-taking by the local banking establishment, and probably retarded economic growth, but it did preserve stability in the political sphere while coping with wrenching structural changes in their economies. It also meant that financial crises, rather than increasing correlations among capital markets, actually tended to decrease them.

Policymakers acting through the maintenance of discount rates established by their respective public banks, therefore, had different concerns, which varied from country to country. Comparing the responses of the several countries that eventually formed the basis for the first global financial market to the systemic crises that struck from time to time, contagion appeared less likely (1890) when the short-term capital markets had been allowed to operate in an interdependent, well-integrated manner before the crisis. Only when differences in interest rate patterns were attempted by countries before a crisis by whatever means-different monetary regimes, informal capital controls, support of fiduciary issues - then an especially severe crisis made common responses more likely to a common shock (1893 and 1907). 


\section{Appendix}

\begin{tabular}{|c|c|c|}
\hline Country & Description & Data Availability \\
\hline \multicolumn{3}{|c|}{ Bank discount rates } \\
\hline Austria & & 1 January 1870-27 June 1914 \\
\hline Belgium & & 1 January 1870-27 June 1914 \\
\hline Denmark & & 10 May 1884-27 June 1914 \\
\hline France & & 1 January 1870-27 June 1914 \\
\hline Germany & Berlin bank rate & 1 January 1870-27 June 1914 \\
\hline Italy & Genoa bank rate & 24 January 1885-27 June 1914 \\
\hline The Netherlands & & 1 January 1870-27 June 1914 \\
\hline Norway & & 6 January 1894-27 June 1914 \\
\hline Portugal & & 24 January 1885-27 June 1914 \\
\hline Russia & St. Petersburg & 1 January 1870-27 June 1914 \\
\hline Spain & & 6 January 1885-27 June 1914 \\
\hline Sweden & & 17 December 1892-27 June 1914 \\
\hline Switzerland & & 17 December 1892-27 June 1892 \\
\hline United Kingdom & & 1 January 1870-27 June 1914 \\
\hline \multicolumn{3}{|c|}{ Open market rates (three-month bills) } \\
\hline Austria & & 1 January 1870-27 June 1914 \\
\hline Australia & $\begin{array}{l}\text { Discount rate for Australian } \\
\text { banks operating in London }\end{array}$ & 10 May 1884-30 December 1893 \\
\hline Belgium & & 1 January 1870-27 June 1914 \\
\hline Denmark & & 10 May 1884-27 June 1914 \\
\hline France & & 1 January 1870-27 June 1914 \\
\hline Germany & Berlin open market rate & 1 January 1870-27 June 1914 \\
\hline India & Bombay bank rate & 10 May 1884-27 June 1914 \\
\hline Italy & Genoa open market rate & 24 January 1885-27 June 1914 \\
\hline The Netherlands & & 1 January 1870-27 June 1914 \\
\hline Norway & & 6 January 1894-27 June 1914 \\
\hline Portugal & & 24 January 1885-27 June 1914 \\
\hline Russia & St. Petersburg open market rate & 4 February 1871-27 June 1914 \\
\hline Spain & & 6 January 1885-27 June 1914 \\
\hline Sweden & & 17 December 1892-27 June 1914 \\
\hline Switzerland & & 17 December 1892-27 June 1914 \\
\hline United Kingdom & & 1 January 1870-27 June 1914 \\
\hline United States & Call money rate in New York City & 27 November 1880-27 June 1914 \\
\hline \multicolumn{3}{|c|}{ Long term bond rates } \\
\hline \multirow[t]{2}{*}{ Austria } & $5 \%$ silver rentes & 2 January 1880-29 December 1899 \\
\hline & $4 \%$ gold rentes & 2 January 1880-December 1913 \\
\hline Belgium & $3 \%$ rentes & 16 January $1885-21$ October 1898 \\
\hline France & $3 \%$ rentes & 2 January 1880-31 July 1914 \\
\hline \multirow[t]{3}{*}{ Germany } & $\begin{array}{l}\text { Prussian consols ( } 4 \% \text { converted } \\
\text { to } 3.5 \% 22 \text { April } 1898)\end{array}$ & 31 December 1880-31 December 1909 \\
\hline & $3 \%$ imperial & 24 August 1894-26 December 1913 \\
\hline & $4 \%$ imperial & 23 November $1894-26$ December \\
\hline \multicolumn{3}{|l|}{1913} \\
\hline Italy & $4 \%$ & 2 January 1880-26 December 1913 \\
\hline The Netherlands & $3 \%$ & 25 August $1882-26$ December 1913 \\
\hline Russia & $5 \%$ & 2 January 1880-31 July 1914 \\
\hline United Kingdom & $3 \% / 2.75 \%$ consols & 2 January 1880-31 July 1914 \\
\hline \multirow{2}{*}{ United States } & $4 \%$ & 2 January 1880-9 August 1907 \\
\hline & $4 \%$ (due 1925 ) & 6 January 1905-31 July 1914 \\
\hline
\end{tabular}




\section{References}

Baig, Taimur, and Ilan Goldfajn. 1999. Financial market contagion in the Asian crisis. IMF Staff Papers 46 (June): 167-95.

Bloomfield, Arthur I. 1959. Monetary policy under the international gold standard, 1880-1914. New York: Federal Reserve Bank of New York.

Bordo, Michael D. 1993. The Bretton Woods international monetary system: A historical overview. In A retrospective on the Bretton Woods system: Lessons for international monetary reform, ed. Michael Bordo and Barry Eichengreen, 3-98. Chicago: University of Chicago Press.

Bordo, Michael D., and Barry Eichengreen. 1999. Is our current international economic environment unusually crisis prone? Unpublished working paper, August.

Bordo, Michael D., and Ronald MacDonald. 1997. Violations of the rules of the game and the credibility of the classical gold standard, 1880-1914. NBER Working Paper no. 6115. Cambridge, Mass.: National Bureau of Economic Research, July.

Bordo, Michael D., and Antu Panini Murshid. 2000. Are financial crises becoming increasingly more contagious? NBER Working Paper no. 7900. Cambridge, Mass.: National Bureau of Economic Research, September.

Bordo, Michael D., and Anna J. Schwartz. 1999. The operation of the specie standard: Evidence for core and peripheral countries, 1880-1990. In The gold standard and related regimes: Collected essays, ed. Michael D. Bordo, 238-317. New York: Cambridge University Press.

Carswell, John. 1993. The South Sea Bubble. Rev. ed. London: Alan Sutton.

Chancellor, Edward. 1999. Devil take the hindmost: A history of financial speculation. New York: Farrar, Straus, and Girous.

Classens, Stijn, and Kristin Forbes, eds. 2001. International financial contagion. New York: Kluwer.

Dawson, Frank G. 1990. The first Latin American debt crisis: The city of London and the 1822-25 loan bubble. New Haven, Conn.: Yale University Press.

de Vries, Jan, and Ad van der Woude. 1997. The first modern economy: Success, failure, and perseverance of the Dutch economy, 1500-1815. Cambridge: Cambridge University Press.

Dickson, P. G. M. 1967. The financial revolution in England: A study in the development of public credit, 1688-1756. London: Macmillan.

Doubleday, Thomas. 1847. A financial, monetary, and statistical history of England from the Revolution of 1688 to the present time. London: Effingham Wilson.

Eichengreen, Barry. 1992. Golden fetters: The gold standard and the Great Depression, 1919-1939. New York: Oxford University Press.

Ferguson, Niall. 2001. The cash nexus: Money and power in the modern world, 17002000. New York: Basic Books.

Flandreau, Marc. 1995. L'or du monde: La France et la stabilité du système monétaire international, 1848-1914 (The gold of the world: France and the stability of the international monetary system.) Paris: L'Harmattan.

1996. The French crime of 1873: An essay on the emergence of the international gold standard. Journal of Economic History 56:849-72.

Forbes, Kristin, and Roberto Rigobon. 1999. No contagion, only interdependence: Measuring stock market co-movements. NBER Working Paper no. 7267. Cambridge, Mass.: National Bureau of Economic Research, July.

Frankel, Jeffrey, and Andrew K. Rose. 1998. The endogeneity of the optimum currency area criteria. Economic Journal 108 (July): 1009-25. 
Gallarotti, Giulio M. 1995. The anatomy of an international monetary regime: The classical gold standard, 1880-1914. New York: Oxford University Press.

Garber, Peter M. 2000. Famous first bubbles: The fundamentals of early manias. Cambridge: MIT Press.

Gayer, Arthur D., Anna Jacobson Schwartz, and W. W. Rostow. 1975. The growth and fluctuation of the British economy, 1790-1850. 2 vols. New York: Barnes and Noble Books.

Goodhart, C. A. E., and P. J. R. Delargy. 1998. Financial crises: Plus ça change, plus c'est la meme chose. International Finance 1 (2): 261-87.

Harris, Ronald. 2000. Industrializing English law: Entrepreneurship and business organization, 1720-1844. New York: Cambridge University Press.

Hoffman, Philip T., Gilles Postel-Vinay, and Jean-Laurent Rosenthal. 2000. Priceless markets: The political economy of credit in Paris, 1660-1870. Chicago: University of Chicago Press.

Hoffman, Philip, and Jean-Laurent Rosenthal. 1995. Redistribution and long-term private debt in Paris, 1660-1726. Journal of Economic History 55 (June): 256-84.

Homer, Sidney, and Richard Sylla. 1991. A history of interest rates. 3rd ed. New Brunswick, N.J.: Rutgers University Press.

Israel, Jonathan. 1995. The Dutch Republic: Its rise, greatness, and fall, 1477-1806. Oxford, U.K.: Clarendon.

Jenks, Leland H. 1927. The migration of British capital to 1875. New York: Knopf.

Kindleberger, Charles P. 1986. The world in depression, 1919-1939. Rev. ed. Berkeley, Calif:: University of California Press.

\section{Press.}

1987. International capital movements. New York: Cambridge University 2000. Manias, panics, and crashes. 4th ed. New York: Wiley.

Lewis, W. Arthur. 1949. Economic survey, 1919-1939. London: Allen and Unwin.

Love, Joseph. 1996. Crafting the third world: Theorizing underdevelopment in Rumania and Brazil. Stanford, Calif.: Stanford University Press.

Marichal, Carlos. 1989. A century of debt crises in Latin America: From independence to the Great Depression, 1820-1930. Princeton, N.J.: Princeton University Press.

Mitchell, B. R. 1962. Abstract of British historical statistics. Cambridge: Cambridge University Press.

Murphy, Antoine. 1997. John Law: Economic theorist and policy-maker. Oxford, U.K.: Clarendon.

Neal, Larry. 1990. The rise of financial capitalism: International capital markets in the Age of Reason. New York: Cambridge University Press.

. 1998. The financial crisis of 1825 and the restructuring of the British financial system. Federal Reserve Bank of St. Louis Review 80 (May-June): 53-76.

2000. How it all began: The monetary and financial architecture of Europe during the first global capital markets, 1648-1815. Financial History Review 7:117-40.

Obstfeld, Maurice, and Alan M. Taylor. 1998. The Great Depression as a watershed: International capital mobility over the long run. In The defining moment: The Great Depression and the American economy in the twentieth century, ed. Michael D. Bordo, Claudia Goldin, and Eugene N. White, 353-402. Chicago: University of Chicago Press.

Odell, Kerry, and Marc D. Weidenmier. 2001. Real shock, monetary aftershock: The 1906 San Francisco earthquake and the panic of 1907. Claremont Colleges Working Paper no. 2001-07. NBER Working Paper no. 9176. Cambridge, Mass.: National Bureau of Economic Research. 
O'Rourke, Kevin, and Jeffrey G. Williamson. 2000. Globalization and history: The evolution of a nineteenth century Atlantic economy. Cambridge: MIT Press.

Palgrave, Robert Harry Inglis. 1903. Bank rate and the money market in England, France, Germany, Holland, and Belgium, 1844-1900. London: J. Murray.

Pressnell, Leslie. 1968. Gold reserves, banking reserves, and the Baring crisis of 1890. In Essays in money and banking in honour of R. S. Sayers, ed. C. R. Whittlesey and J. S. G. Wilson, 167-228. Oxford, U.K.: Clarendon.

Redlich, Fritz. 1959. Contributions in the Thirty Years' War. Economic History Review 12 (December): 247-54.

Riley, James C. 1980. International government finance and the Amsterdam capital market. Cambridge: Cambridge University Press.

Schumpeter, Joseph A. 1939. Business cycles: A theoretical, historical, and statistical analysis of the capitalist processes. New York: McGraw-Hill.

Tracy, James. 1985. A financial revolution in the Habsburg Netherlands. Berkeley: University of California Press.

_ ed. 1990. The rise of merchant empires, 1500-1800. Cambridge: Cambridge University Press.

Williamson, Jeffrey G. 1995. The evolution of global labor markets since 1830: Background evidence and hypotheses. Explorations in Economic History 32 (April): 141-96.

Wilson, Charles. 1941. Anglo-Dutch commerce and finance in the eighteenth century. Cambridge: Cambridge University Press.

Ziegler, Dieter. 1990. Central bank, peripheral industry: The Bank of England in the provinces, 1826-1913. Leicester, U.K.: Leicester University Press.

\section{Comment Mark P. Taylor}

The last decade of the twentieth century witnessed a spate of international financial and exchange rate crises, including the domino collapse of the European exchange rate mechanism in 1992-93, the 1994 Mexican "tequila hangover," the Asian "flu" of 1997-98, and the turmoil in emerging and global financial markets following the August 1998 Russian crisis.

Not surprisingly, this highly dramatic sequence of events led to the rapid expansion of economics research into exchange rate and financial crises. Part of this research has been concerned with examining the nature of financial crises and developing methods for anticipating them and understanding the channels through which they tend to spread. Another, related strand of research has tracked the policy debate that naturally followed, concerning how best to deal with crises and their transmission at a policy level and, in particular, the role of the International Monetary Fund (IMF) — whether it should act as a lender of last resort and add liquidity in times of crisis or whether its role is more to police sound macroeconomic and financial structural reform.

Mark P. Taylor is professor of macroeconomics at the University of Warwick. 
Some, for example, would argue that the IMF seriously exacerbated the 1997-98 crisis in East Asia by calling for extensive structural reforms before making adequate official funding available, thereby delaying the restoration of investor confidence, allowing the collapse of the Asian currencies, andby insisting on a tightening of monetary policy - exacerbating the effects of the crisis by generating domestic credit crunches. On the other hand, those advocating structural reform above all else might argue that this was a perfectly correct judgment call, since without structural reform official funding would have been simply wasted - the IMF was just the unfortunate messenger of some economic home truths.

On the sound principle that those who ignore the lessons of history are condemned to repeat the mistakes of the past, Neal and Weidenmier provide in their paper a wide-ranging discussion of a set of well-known financial crises over the past three and a half centuries, ranging from the Dutch tulip mania of the seventeenth century through the Mississippi and South Sea bubbles of the eighteenth century, the first Latin American debt crisis of 1825 , the 1873 crisis, and three crises of the international gold standard period, before focusing their analysis on twentieth century episodes - first the Crash of 1929 and then some of the more recent crises mentioned in the opening paragraph of this comment. They pay special attention to three major crises that sprung up in the gold standard period of 1880 1913, which they divide into an initial period of mild gold deflation from 1880 to 1896 and a subsequent period of mild gold inflation from 1897 to 1913.

They conclude that countries with weak fundamentals were well advised not to follow the example of the Bank of England during crisis episodes, in terms of lending at penalty rates of interest, but rather to pursue a policy of "credit rationing" whereby they carried on lending at their previous discount rates but only to their most solvent customers.

The paper is an impressive display of scholarship, although I do have some misgivings about the clarity of the hypotheses tested in the paper. In part, this results from the surprisingly slippery nature of the term contagion. The authors define this early on as "the spread of a financial crisis from the country of origin to innocent trading partners or geographical neighbors whose financial fundamentals are sound." In fact, however, contagion has proved hard to pin down (see, e.g., Masson 1999; Edwards 2000; Corsetti, Pericoli, and Sbracia 2002). Pericoli and Sbracia (2001), for example, list no fewer than five definitions of contagion current in the literature.

In their empirical work, however, Neal and Weidenmier implicitly use a definition based on the work of Forbes and Rigobon (2002). This can be set out briefly as follows. Let $r_{i t}$ be the return on an asset at time $t$ for the $i$ th country and let $n_{i t}$ be a country-specific, or national, component. Then Forbes and Rigobon assume a linear relationship between returns in the $i$ th country and returns in the reference country $j$ of the form 


$$
r_{i t}=\beta_{i} r_{j t}+n_{i t}, \quad i=1,2, \ldots m ; i \neq j,
$$

where $E\left(r_{i t} n_{i t}\right)=0$ and the variance of idiosyncratic national shocks, $\operatorname{var}\left(n_{i t}\right)$, is assumed to be constant across tranquil and crisis periods. The country-specific coefficients $\beta^{i}$ may be taken to measure the strength of a country's interconnection to country $j$. Thus we have

$$
\operatorname{var}\left(r_{i t}\right)=\beta_{i}^{2} \operatorname{var}\left(r_{j t}\right)+\operatorname{var}\left(n_{i t}\right),
$$

and

$$
\operatorname{cov}\left(r_{i t}, r_{i t}\right)=\beta_{i} \operatorname{var}\left(r_{j t}\right)
$$

so that

$$
\operatorname{corr}\left(r_{i t}, r_{i t}\right)=\beta_{i} \sqrt{\frac{\operatorname{var}\left(r_{j t}\right)}{\beta_{i}^{2} \operatorname{var}\left(r_{j t}\right)+\operatorname{var}\left(n_{i t}\right)}} .
$$

From equation (4), however, we can see that the correlation of the two asset returns is increasing in the variance of the reference-country asset returns. Thus, in times of increased volatility, correlations will rise. If this is the case and the coefficient $\beta_{i}$ has remained constant, Forbes and Rigobon define this as interdependence, rather than contagion. If, however, there has been a shift in this structural parameter brought about by the crisis-perhaps due to herding or other effects that force a disconnect - then this is taken as evidence of contagion. In order to test whether the increase in correlation is due to such a structural shift (contagion) or is due simply to a common rise in volatility with the underlying structural link (1) constant (interdependence), Forbes and Rigobon thus suggest a measure of correlation that adjusts for shifts in volatility of this kind. In their empirical work, the result is to downgrade a number of international crises from instances of contagion to instances of interdependence (i.e., a nonzero but stable $\beta_{i}$ ).

Corsetti, Pericoli, and Sbracia (2002), however, argue that the results in these papers reflect restrictive assumptions (restrictions on the countryspecific effects) and that a more general specification leads to a finding of greater contagion. Drawing on the finance literature, they suggest a singlefactor model for $r_{i t}$ and $r_{j t}$ of the form

$$
\begin{gathered}
r_{i t}=\gamma_{i} \kappa_{t}+n_{i t}, \quad i=1,2, \ldots m, i \neq j \\
r_{j t}=\gamma_{i} \kappa_{t}+n_{j t},
\end{gathered}
$$

where $\kappa_{t}$ is the unobserved factor common to all of the countries under consideration and $\gamma_{i}$ is the country-specific factor loading. The terms $n_{i t}$ and $n_{j t}$ again represent idiosyncratic national components. Substituting out for the common factor in equation (5) using equation (6), we have

$$
r_{i t}=\beta_{i}^{\prime} r_{j t}+n_{i t}^{\prime}, i=1,2, \ldots m,
$$

where 


$$
\beta_{i t}^{i}=\frac{\gamma_{i}}{\gamma_{j}}, n_{i t}^{\prime}=\left(n_{i t}-\frac{\gamma_{i}}{\gamma_{j}} n_{j t}\right) .
$$

Now, although equation (7) is superficially of the form of equation (1), the only case where this more general model collapses to the Forbes-Rigobon setup is under the unrealistic assumption that the idiosyncratic national component in the reference country is identically equal to zero, so that the asset return in the reference country effectively becomes identical to the international common factor. Otherwise, at least two of the conditions that are crucial to the results derived by Forbes and Rigobon are violated. First, $E\left(r_{i t} h_{i t}^{\prime}\right) \neq 0$, and second, insofar as the reference country experiences increased volatility at the time of the crisis, $\operatorname{var}\left(n_{i t}^{\prime}\right)$ will not be constant across tranquil and crisis periods. Both of these violations will tend to induce a bias in the Forbes-Rigobon statistic, and although bias from the first source is difficult to sign, bias from the second source will tend to bias the statistic toward nonrejection of the null hypothesis of no structural shift (i.e., no contagion; see Corsetti, Pericoli, and Sbracia 2002 for further details).

The implication, alas, is that unless one is willing to make quite stringent assumptions about the factors driving international asset returns, the Forbes-Rigobon statistic may well be biased, and probably toward nonrejection of the null hypothesis. Hence, some of the empirical results derived in Neal and Weidenmier's paper may be brought into question.

While this is a shortcoming of the paper, it is not, in the present author's opinion, fatal, and it is one for which the authors should be exonerated - at press time for this volume, Forbes and Rigobon (2002) had literally just been published. Moreover, the verbal argument and the wealth of analysis contained in the Neal and Weidenmier paper remain an impressive tour de force and contribution to scholarship. Neal and Weidenmier have, moreover, put together an important database for the gold standard period and further empirical analysis therefore seems both warranted and possible.

Although the present author is clearly partisan, one way in which they might fruitfully address the issues of interest is through the commonvulnerabilities approach suggested by Mody and Taylor (2002). These authors begin with a common factor model of the kind of equations (5) and (6) and estimate the unobservable common factor using Kalman filtering techniques. ${ }^{1}$ As a step to understanding what movements in this common factor are due to underlying macroeconomic and financial similarities across a region (the "common vulnerability") and what part is unanticipated during a crisis (contagion) they then extract the "expected" changes by relating the common factor to a vector of underlying (regional) macroeconomic and financial indicators. As a result, they are able to assess the

1. Mody and Taylor are in fact concerned with modeling movements in the exchange market pressure index during the East Asian crisis, although their approach could be applied equally to asset returns. 
underlying factors driving common vulnerability across a region. Since Neal and Weidenmier are concerned with whether the countries they examine were prone to the spread of crisis due to weakness in the underlying fundamentals, this may be a useful way to proceed with further analysis.

\section{References}

Corsetti, Giancarlo, Marcello Pericoli, and Massimo Sbracia. 2002. Some contagion, some interdependence: More pitfalls in the tests of financial contagion. Yale University, Department of Economics. Mimeograph.

Edwards, Sebastian. 2000. Contagion. World Economy 23:873-900.

Forbes, Kristin J., and Roberto Rigobon. 2002. No contagion, only interdependence: Measuring stock market co-movement. Journal of Finance 57 (5): 2223-61.

Masson, Paul. 1999. Contagion: Monsoonal effects, spillovers, and jumps between multiple equilibria. In The Asian financial crisis, ed. P. R. Agénor, M. Miller, D. Vines, and A. Weber, 265-80. New York: Cambridge University Press.

Mody, Ashoka, and Mark P. Taylor. 2002. Common vulnerabilities. International Monetary Fund, Research Department. Mimeograph.

Pericoli, Marcello, and Massimo Sbracia. 2001. A primer on financial contagion. Banca d'Italia. Mimeograph. 